NBER WORKING PAPER SERIES

\title{
TRADE AND INDUSTRIAL POLICY REFORM IN LATIN AMERICA
}

Sebastian Edwards

Working Paper No. 4772

\author{
NATIONAL BUREAU OF ECONOMIC RESEARCH \\ 1050 Massachusetts Avenue \\ Cambridge, MA 02138 \\ June 1994
}

This is a revised version of a paper presented at the conference "Macroeconomic Structural and Social Policies for Growth: The Evolving Latin American Experience", Mangaratiba, Rio de Janeiro, Brazil, March 1994. I am indebted to my discussants and conference participants for useful comments. I am thankful to Fernando Losada for excellent research assistance. This paper is part of NBER's research programs in International Finance and Macroeconomics and International Trade and Investment. Any opinions expressed are those of the author and not those of the National Bureau of Economic Rescarch. 


\title{
TRADE AND INDUSTRIAL POLICY REFORM IN LATIN AMERICA
}

\begin{abstract}
This paper documents and evaluates the process of trade reforms in Latin America from the mid-1980s until 1993. It provides an analytical and historical discussion of the consequences of industrial policies in the region, from the early 1950 s when import-substitution ideas were supported by the Economic Commission for Latin America to the 1990s when liberal regimes were embraced.

A careful distinction is made between policies based on strict import substitution and policies that combine high and uneven import tariffs with export promotion. Additionally, the role of supporting policies to assure the success of trade liberalization is assessed. Important questions related to the sequencing of economic reform are discussed in detail, with particular emphasis on the proper sequencing of stabilization and trade reform policies.

The extent of trade reform in Latin America is also discussed. The analysis concentrates on the evolution of productivity and exports, and it deals with several countries' experiences. The role of real exchange rates in the trade liberalization process is studied, and the recent trend towards appreciation observed in many countries in the region is scrutinized.

Finally the paper contains an analysis of the recent attempts at reviving regional integration agreements, and of the consequences of the completion of GATT for Latin American nations.
\end{abstract}

Sebastian Edwards

The World Bank

Room I-8459

1818 H Street, NW

Washington, D.C. 20034

and NBER 
Most of the Latin American countries began to open up to the rest of the world in the late 1980s. This process is perhaps the most impressive achievement of the structural adjustment program that followed the debt crisis, and it has effectively put an end to more than four decades of active industrial policies based on import substitution.

However, the process leading to these trade reforms has not been easy. As recently as the mid-1980s the protectionist view was still influential in many parts of Latin America. In fact, the debt crisis of 1982 provided a new impetus to the protectionist paradigm. In a way that resembled the arguments of the 1930s and 1940s, since a number of authors interpreted the crisis as a failure of "the world economic order" and argued that the only way for Latin America to avoid a recurrence of this type of shock was to further isolate itself from the rest of the world through selective protectionism and government intervention. ${ }^{1}$ This perspective was vividly defended by Lance Taylor (1991, p. 119) who argued that "trade liberalization strategy is intellectually moribund" and that "development strategies oriented internally may be a wise choice towards the century's end" (p. 141).

In the mid-1980s Latin America's external sector was the most distorted in the world. For example, as can be seen in Table 1, Central America had the highest degree of import protection-both in terms of tariff and non-tariff barriers-among developing countries, with South America following closely behind. However, by 1987-88 it became apparent that a permanent solution to the region's economic problems would imply a fundamental change in its development strategy. In particular policymakers began to realize that the long-standing protectionist trade policy was at the heart of the regions problems. During the late 1980s and early 1990 s and with the assistance of the multilateral institutions, a larger and larger number of countries began to reduce their levels of protection and to reform their development views. The trade reform process has proceeded at an increasingly rapid pace. Tariffs have been drastically slashed, in many countries import licenses and prohibitions have been completely eliminated, and a number of countries are actively trying to sign free trade agreements with other Latin American nations as well as with the United States.

The purpose of this paper is to document and evaluate the process of trade reform in Latin

\footnotetext{
${ }^{1}$ Griffith-Jones and Sunkel (1986).
} 


\title{
Table 1 - IMPORT PROTECTION IN THE DEVELOPING WORLD: 1985
}

TOTAL TARIFF

PROTECTION (a)
(Percent)

NON-TARIFF BARRIERS

COVERAGE (b)

60

100

17

23

39

85

36

86

5

11

25

21

\begin{abstract}
(a) Includes tariffs and para-tariffs
(b) Measures as a percentage of import lines covered by non-tariff barriers. The data on both tariffs and NTBs reported here are weighted averages
\end{abstract}

Source: Erzan et al. (1989) 
America. ${ }^{2}$ The paper is organized as follows. Section I provides an analytical and historical discussion of the consequence of the traditional industrial policies in Latin America. A distinction is made between policies based on strict import substitution, and policies that combined high and uneven import tariffs with export promotion. Section II deals with some of the analytics of trade liberalization reforms. This section also includes a discussion on the role of supporting policies in assuring the success of a trade liberalization reforms. Important questions related to the sequencing of economic reform are discussed in some detail. In particular, emphasis is given to the issue of the appropriate sequencing of stabilization and trade reform policies. In Sections III and IV the extent of trade reform in Latin America is discussed, and some of the results of the reforms are analyzed. The analysis concentrates on productivity and exports, and deals with the experiences of several countries. Section $\mathrm{V}$ deals with the role of real exchange rates in a trade liberalization process, and analyzes the recent trend towards real appreciation in most countries in the region. Section VI concentrates on recent attempts at reviving regional integration agreements, on the future prospects for free trade agreements with the United States, and on the significance of the recent GATT agreement for the Latin American countries.

I.- Protectionism, Industrial Policy and Export Promotion in Latin America: Analytical Issues and Historical Experience

The recent trade liberalization programs in Latin America have sought to reverse protectionist policies that for decades have been at the heart of the region's development strategy. In order to place these reforms in perspective it is useful to first analyze the way in which the protectionist policies affected the economic structure of Latin America, and to discuss what were the expected effects of the liberalization policies.

\section{I.1. The Economic Consequences of Protectionist Industrial Policies}

The Great Depression had a fundamental impact on the Latin American economies. Terms of trade plummeted-in some cases such as Brazil, Chile and Colombia by almost $50 \%$-capital inflows stopped, and real income was severely reduced. The effects of the decline in

2 The material presented in this paper is based on some of the work I have done on this subject during the last few years. In particular, it draws on Chapter 5 of the report Latin America and the Caribbean a Decade After the Debt Crisis, The World Bank, September 1993. See the references to this paper for a list of works related to this topic. 
world-wide demand for raw materials in 1929-30 was compounded by the adoption of protectionist policies in the U.S. and Europe, including the Smoot-Hawley Tariff Act in 1930 and the British Abnormal Importations Act of 1931.

Most Latin American countries reacted to these events by abandoning convertibility, devaluing their currencies and imposing tariff barriers. Diaz-Alejandro (1981) has described these policies as follows: ${ }^{3}$

Exchange rate devaluations were not the only measures undertaken .... [T] here were also increased tariffs, import and exchange controls, bilateral clearing agreements and ... multiple exchange rates.

It has generally been thought that sustained protectionism became dominant throughout Latin America in the early 1930s, if not earlier. ${ }^{4}$ However, Thorp (1992) has recently argued that in the mid- to late-1930s a number of countries in the region-especially Argentina, Brazil and Chile-implemented substantial trade liberalization policies aimed at encouraging openness and outward orientation. She has argued that export expansion played a key role in the Latin American recovery towards the end of the decade of the 1930s. The eruption of World War II put an end to this episode of export-led growth, and once again the Latin American countries faced the adverse world shocks by resorting to protectionism and inward-looking policies. However, this time the end of the foreign disturbances was not followed by a new period of openness and reinsertion into the world trade economic system. By the late 1940s and early 1950s protectionist policies based on import substitution were well entrenched and constituted, by far, the dominant perspective. ${ }^{5}$

The creation of the United Nations Commission for Latin America (CEPAL/ECLAC) helped provide an intellectual underpinning for the protectionist position. In particular, the writings of Raul Prebisch (1950) ${ }^{6}$ and Hans Singer (1950) provided an aura of respectability to import substitution

${ }^{3}$ See, also, Furtado (1969) and Bianchi and Nohara (1988).

${ }^{4}$ See Leff (1969) on Brazil. Bianchi and Nohara (1988) discuss this issue for Latin America as a whole.

${ }^{5}$ Diaz-Alejandro (1981).

${ }^{6}$ Raul Prebisch was a remarkable intellectual force that greatly shaped early Latin American economic thinking. He was the governor of the Argentinean Central Bank in the 1930s and early 1940s, a period when he applied orthodox policies. In 1947 Prebisch 
policies. These authors' thinking was based on two fundamental premises: (1) a secular deterioration in the international price of raw materials and commodities would result, in the absence of industrialization in the LDCs, in an ever-growing widening of the gap between rich and poor countries, and (2) in order to industrialize, the smaller countries required (temporary) assistance in the form of protection to the newly emerging manufacturing sector. This reasoning was closely related to the infant industry argument for industrialization. ${ }^{7}$ Between the 1950s and 1970s a large number of development economists embraced the inward-oriented view, and devoted enormous energy to design planning models that relied heavily on the import substitution ideas. This view became clearly dominant, being taught in most Latin American universities with great zeal ${ }^{8}$

Prebisch's position developed as a criticism of outward orientation, which he considered to be incapable of permitting the full development of the Latin American countries. He argued that development required industrialization through import substitution, and that this could be "stimulated by moderate and selective protection policy" (Prebisch, 1984, p. 179). Eventually, however, the degree of protection to the incipient industries was anything but moderate, as more and more sectors required additional cariffs and other types of government support to continue facing foreign competition. ${ }^{9}$

During the early years of import substitution important heavy industries were created in the larger countries, and the basis for the development of a domestic manufacturing sector were set. During the 1950s the industrial sector grew at rapid real rates, topping in some cases-Brazil and

published the first Spanish language guide to Keynes' General Theory. On the evolution of his thinking, see Prebisch (1984). See also, chapter 1 of Iglesias (1992) and Solis (1988).

${ }^{7}$ An interesting summary of this view can be found in Prebisch (1984). Albert Hirschman (1968) provided an early "soul-searching" assessment of the disappointing results experienced under ISI. A review of import substitution theories appears in Henry Bruton (1989). For a discussion of trade policies in the context of Latin America's historical development, see Albert Fishlow (1987).

${ }^{8}$ See, for example, the popular Paz and Sunkel (1971) textbook for discussion on economic policy in the context of the structuralist and protectionist view. See also the text on international economics by Ffrench-Davis and Griffin (1967). Castro and Lessa (1969) provided a popular, and widely used, principles text that discussed basic economic issues from a structuralist perspective.

${ }^{9}$ Balassa (1982); Little et al. (1971). 
Mexico, for example-the $8 \%$ annual mark (Elias, 1992). With the industrialization process, however, an array of restrictions, controls, and often contradictory regulations evolved. In most countries lobbying developed swiftly as a way to secure the rents created by the maze of controls. It was, in fact, because of import restrictions that many of the domestic irdustries were able to survive. As a consequence, many of the industries created under the import substitution strategy were quite inefficient. Krueger (1981) and Balassa (1982) found that this inward-looking strategy generated rentseeking activities and resulted in the use of highly capital-intensive techniques, which hampered the creation of employment throughout the region. ${ }^{10}$

In most countries, starting in the late 1940s, import substitution was accompanied by an overvalued domestic currency that precluded the development of a vigorous nontraditional export sector. ${ }^{11}$ In an early study using data from the 1960s Balassa (1971) found that the Latin American countries in his sample-Brazil, Chile and Mexico-had some of the most distorted foreign trade sectors in the world. These findings coincide with those obtained by Little et al (1970) in their pioneer study on trade policy and industrialization in the developing world. These authors persuasively argued that the high degree of protection granted to manufacturing in Latin America resulted in a serious discrimination against exports, in resource misallocation, inefficient investment and deteriorating income distribution. They further argued in favor of the reversal of protectionist policies as the center of any reformulation of Latin America's development strategy. The agricultural sector was particularly harmed by real exchange rate overvaluation. The lagging of agriculture became one of the most noticeable symptoms of many countries economic problems of the 1950 s and 1960s. The overvaluation of the real exchange rate played an important political role during this period, since it kept down prices of imported goods consumed by urban dwellers. ${ }^{12}$

\footnotetext{
${ }^{10}$ See chapter 5 for a further elaboration.
}

${ }^{11}$ This point was strongly made by Diaz-Alejandro (1970) in his monumental study on the external sector in Argentina. See also Diaz-Alejandro (1978) work on Colombia. See Edwards $(1988,1989)$ for discussions on real exchange rate misalignment. It may be argued that, given the level of protectionism that prevailed during this period, observed (and appreciated) real exchange rates were at an "equilibrium" level. However, under this interpretation the highly appreciated real exchange rates still discourage non-traditional exports. See chapter 5 for greater details.

${ }^{12}$ The discrimination of agriculture during this period contrasts sharply with the case of East Asia, where serious efforts were made to avoid harming that sector. See The World 
In many countries-especially in Argentina, Brazil, Chile, Colombia, Peru, Uruguay and Venezuela-fiscal imbalances became a staple of government policies. However, the dominant view did not consider this to be an overly serious matter; it was, in fact, believed that fiscal disequilibrium was only indirectly related to inflation. ${ }^{13}$ The inflationary problem became particularly serious in Chile where the rate of increase of consumer prices averaged $36 \%$ per annum during the 1950 s, reaching a peak of $84 \%$ in 1955 .

The discouragement of export activities took place through two main channels: first, import tariffs, quotas and prohibitions increased the cost of imported intermediate materials and capital goods used in the production of exportables, reducing their effective rate of protection. In fact, for years a vast number of exportable goods, especially those in the agricultural sector, had negative rates of protection to their value added. Second, the maze of protectionist policies resulted in real exchange rate overvaluation that reduced the degree of competitiveness of exports. This anti-export bias explains the poor performance of the export sector, including the inability to aggressively develop non-traditional exports, during the twenty years preceding the debt crisis. Paradoxically, policies which were supposed to reduce Latin America's dependency on the world-wide business cycle, ended up creating a highly vulnerable economic structure where the sources of foreign exchange were concentrated on a few products intensive in natural resources, and where imports were concentrated on a relatively small group of essential goods (CEPAL, 1992a).

A second general and important consequence of traditional protective trade policies was the creation of a largely inefficient manufacturing sector in most countries. Instead of granting short term protection to help launch new activities, high tariffs, quotas and prohibitions became a fixture of the region's economic landscape. An important consequence of the pressures exercised by lobbyists and interest groups was that the protective structure in Latin America became extremely uneven, with some sectors enjoying effective tariff rates in the thousands, and others suffering from negative value added protection (Edwards 1992). Moreover, as it is argued below, in the 1970s interest group pressures resulted in the superimposition of an array of special export subsidies for a handful of firms that were deemed to be strategically important (Nogues, 1990).

Bank (1993).

${ }^{13}$ See Sunkel $(1960)$ for the classical piece on the structuralist view on inflation. Dornbusch and Edwards (1990) examine these issues from the more extreme populist perspective. 
The protectionist policies also had serious effects on labor markets. In particular, the protection of capital-intensive industries affected the region's ability to create employment. A number of studies have shown that in developing countries more open trade regimes have resulted in higher employment and in a more even income distribution than protectionist regimes. For example, after analyzing in detail the experiences of ten countries Krueger (1983) concluded that exportable industries tended to be significantly more labor intensive than import competing sectors. In the conclusions to this massive study Krueger argues that employment has tended to grow faster in outward-oriented economies and that the removal of external sector distortions tends to help the employment creation process in most developing nations. These results were broadly supported by other cross country studies, including Balassa (1982) and Michaely et al (1991).

In terms of income distribution the protective system generated large benefits to local industrialists-and in particular to those able to obtain import licenses and concessions-and to urban workers. This, of course, was achieved at the cost of depressing earnings and incomes of rural workers. As is discussed in Edwards (1993), for example, during the 1970s ihcome distribution was significantly more unequal in Latin America than in Asia.

To sum up, although several decades of protectionist policies accomplished the goal of creating an industrial sector in Latin America, this was achieved at a high cost. Exports were discouraged, the exchange rate became overvalued, employment creation lagged behind, and massive amounts of resources-including skilled human talent-were withdrawn from the productive sphere and devoted to lobbying for an ever-favorable treatment of different sectors of the economy. ${ }^{14}$ An increasing number of comparative studies in the 1980s made the shortcomings of the Latin American development strategies particularly apparent. In the aftermath of the debt crisis the long stagnation, and even retrogression, of the region's export sector-with an average rate of decline of $1 \%$ per year between 1965 and 1980--became particularly painful to the local public, analysts and policymakers.

\subsection{Industrial Policy and Export Promotion}

As discussed above, after an auspicious beginning, the import substitution strategy began to

${ }^{14}$ As discussed in some detail in chapter 3 , most authors agree that the import substitution process rapidly run into difficulties once low-technology consumer goods had been "substituted". As countries tried to move towards producing more sophisticated goods-including capital goods and machinery-they ran into an increasingly up-hill battle. See Hirschman (1968) and Fishlow (1985). See also the discussion in chapter 8. 
run into difficulties during the late 1950s and early 1960s. At that time most of the obvious substitutions of imported goods had already taken place, and the process was rapidly becoming less dynamic (Hirschman, 1968). For example, during the 1960 s total real industrial production grew in most countries at one half the annual rate of the previous decade (Elias, 1992). During the 1960s an increasing number of politicians and economists began to agree that Latin America was facing longrun economic problems. It was generally recognized that the easy phase of the import substitution process had ended, and that inflation and the recurrent crises of the external and agricultural sectors had become serious obstacles for reassuming growth (CEPAL, 1967). Further, the increasingly unequal distribution of income and the unemployment problem represented serious challenges to any new economic program. Although most experts pointed out that low rates of domestic savings and investment represented an important obstacle for growth, they differed markedly on some other aspects of their diagnosis, and on the proposed policy packages to take the country out of its relative stagnation. ${ }^{15}$ At this time the simple import substitution policies came under attack from two flanks: on the one hand, a small number of economists, sometimes associated with the monetarist position, argued for orthodox-type stabilization programs based on fiscal restraint and a greater reliance on market forces. ${ }^{16}$ On the other hand, a growing number of intellectuals in the Marxist tradition-including the group known as "dependencistas"-argued that there was too little government presence in economic decisions, and postulated a massive move towards full-fledged planning, in the Eastern-European style. ${ }^{17}$

Facing this two-prong attack, the structuralist thinkers eventually concluded that their policies had to be reformed. Fishlow (1985) notes that the dominant economic view in Latin America experienced two important developments during the 1960s. First, import substitution was expanded from the country sphere to the regional level, and a number of attempts to create regional trading agreements were undertaken. Perhaps the most comprehensive of these was the Andean Pact created

${ }^{15}$ CEPAL played an important role in developing this diagnosis.

${ }^{16}$ No serious recommendations were made, however, at introducing deep structural changes, such as privatizing government-owned firms.

${ }^{17}$ See Fishlow (1987) for a discussion of these competing criticisms of import substitution. Edwards and Edwards (1991) discuss this problem from Chile's perspective. See, also, Sheahan (1987) and Cardoso and Helwege (1991). Vuskovic (1969) provides one of the most eloquent defenses of the dependencista position. 
in 1969 and grouping Chile, Bolivia, Peru, Ecuador, and Colombia, and later, Venezuela. However, the proposed regional arrangements did not tackle the high levels of protection and distortions imposed in the previous 20 years. In fact, in the Andean Pact the proposed common external tariff was extremely high and uneven, representing the expansion of the traditional structuralist thinking to a supra-national level. ${ }^{18}$ The evolution of integrationist attempts in the region is addressed in greater detail in Section IV of this paper.

The second development discussed by Fishlow (1985) was the recognition of the importance of capital inflows as a way to supplement domestic savings and finance higher rates of capital accumulation. However, this option was centered around official capital flows through multilateral institutions, and did not give private flows a significant role. Also, no specific recommendations were made to alter the basic incentive structure of the economy, or to provide a greater role to market forces in long run development strategies.

In the late 1960 s and 1970 s the structuralist view continued to evolve, as it became increasingly evident that the degree of dynamism of most Latin American economies was in rapid decline. In particular, in a number of countries the expansion of exports became an important component of otherwise traditional economic programs. Brazil provides, perhaps, the clearest example of a strategy based on expanding manufacturing exports with the aid of an aggressive industrial policy, based on export subsidies, tax allowances and subsidized credit to selected industries. At the macroeconomic level this industrial policy was supplemented by an active crawling peg exchange rate system aimed at avoiding real exchange rate overvaluation. ${ }^{19}$

Although this policy resulted in a very rapid rate of growth of GDP and manufacturing exports, Brazil's economic base remained somewhat rigid and fragile. ${ }^{20}$ As Fishlow (1991) has argued, after decades of an industrialization strategy based on protective policies, Latin America, and especially Brazil, had relatively high wages and its exports could not become the "engine of growth" as in East Asia. In spite of expanding at a rapid pace, exports still failed to relax the required foreign exchange constraint that for years had affected most countries. As a consequence of this, during the

${ }^{18}$ See Edwards and Savastano (1988).

19 See Rabello de Castro and Ronci (1991) for a critical view of 60 years of development policy in Brazil.

${ }^{20}$ Coes (1991) provides a thorough evaluation of Brazil's attempts at encouraging exports during the 1970s. 
1970 s virtually every country in the region resorted to heavy foreign borrowing in order to obtain foreign exchange. The rapid accumulation of debt made these economies particularly vulnerable, as the region painfully learned in 1982.

An important question is why wasn't export promotion more successful in Latin America? After all, industrial policies explicitly aimed at encouraging exports were implemented aggressively and very successfully in many East Asian countries. For example, starting in the 1960 s an aggressive export promotion scheme became an important complement of the Korean trade liberalization strategy. Throughout the years exports have been subsidized through a number of channels, including (a) direct cash subsidies (until 1964); (b) direct tax reductions (until 1973); (c) interest rate preferences; (d) indirect tax reductions on intermediate inputs; and (e) tariff exemptions to imported intermediate materials. ${ }^{21} \mathrm{Kim}(1991)$ has recently calculated that these subsidies were reduced from 23\% to zero between 1963 and 1983. He has argued, as others have, that in the case of Korea, export subsidies played an important role during the earlier years of the Korean export boom. ${ }^{22}$ A recent massive study undertaken by the World Bank (1993) has explored with great detail the causes behind the East Asian export success. It is argued that in most cases the government organized "contests" among private firms, with export performance as the main criteria to determine "winners". Those firms with a strong export record were rewarded with access to preferential credit and other types of special treatment. This study suggests that by picking "exports" as the general activity to be rewarded, rather than production in a particular sector (e.g., steel), the East Asian nations avoided major distortions and, in particular, were able to minimize the extent of rent seeking activities. In that sense it may be argued that while the Latin American export promotion policies and especially those developed in Brazil - subsidized selected "industries" which were deemed as having an export potential, the East Asia government policies were based on whether the final destination of production was, in effect, the world market.

Lin (1988) has compared trade policies in Korea, Taiwan and Argentina. His computations indicate that in the 1970s the overall rate of effective protection was $10 \%$ in South Korea, $5 \%$ in Taiwan and $47 \%$ in Argentina. The contrast was even bigger in the manufacturing sector, where the effective rates of protection were $-1 \%$ in Korea, $19 \%$ in Taiwan and almost $100 \%$ in Argentina.

${ }^{21}$ See Kim (1991) for details on the different export promotion schemes used.

${ }^{22}$ In Latin America, there has been a controversy on the actual effectiveness of export subsidies. See, for example, Nogues et al. (1992). 
These differences in protective rates affected relative incentives, generating a substantial anti-export bias in Argentina. Modern theories of economic growth have linked openness with productivity growth: more open economies tend to engage in technological innovation faster, exhibiting more rapid productivity improvements. According to Lin (1988) labor productivity increased at an $8.7 \%$ annual rate in Korea during 1973-85, and only at $0.5 \%$ per year in Argentina. The vigorous growth experienced by other East Asian countries-including the second generation "miracle" countries, Malaysia, Thailand and Indonesia-since the late 1980s has added impetus to the idea that a development path based on openness and market orientation can be extremely rewarding. Increasingly Latin American leaders are turning towards East Asia for inspiration and economic partnership.

A number of authors have argued that the conduct of macroeconomic policy constitutes a second crucial difference between East Asia and Latin America. ${ }^{23}$ As has been extensively documented by a number of authors, inflation has been significantly higher in the Latin American nations than in the East Asian countries. Moreover, Latin America has also been affected by higher inflation variability and real exchange rate volatility. The greatest advantage of a stable macroeconomic environment is that it reduces uncertainty, encouraging investment. Moreover, to the extent that the real exchange rate is stable, investment in the tradables sector will increase, as will exports. Sachs (1988) and Fischer (1988), among others, have pointed out that in the adjustmentcum-reform process, it is more convenient to achieve macroeconomic stability before trade is liberalized in the developing countries. Based on the experiences of Korea, Taiwan and Japan, Sachs (1988) has argued that massive and deep tariff reduction has to take place after macro stabilization is firmly in place. ${ }^{24}$ This issue is addressed with greater detail in the next section.

\section{Trade Liberalization: Expected Results and Transitional Problems}

The main objective of trade liberalization programs is to reverse the negative consequences of protectionism and, especially, its anti-export bias. According to basic theory, a trade liberalization process will result in a reallocation of resources according to comparative advantage, in a reduction of

${ }^{23}$ Sachs (1987).

${ }^{24}$ See Edwards (1992) for a general discussion on the sequencing of economic reform. See, also the discussion in chapter 4 of this report. 
waste, and in a decline in imported goods prices. ${ }^{25}$ Moreover, to the extent that the new trade regime is more transparent-for example, through a relatively uniform import tariff-it is expected that lobbying activities will be greatly reduced, releasing highly skilled work from "unproductive" jobs. According to traditional international trade theory it is expected that once negative effective rates of protection and overvalued exchange rates are eliminated, exports will not only grow rapidly, but will also become more diversified.

From a growth perspective the fundamental objective of trade reforms is to transform international trade into "the engine of growth". In fact, newly developed models of "endogenous" growth have stressed the role of openness. ${ }^{26}$ For example, Romer (1989) has developed a model where by taking advantage of larger markets- "the" world market - an open economy can specialize in the production of a relatively larger number of intermediate goods and, thus, grow faster. Other authors have recently concentrated on the relationship between openness, technological progress, and productivity growth. Grossman and Helpman (1991) and Edwards (1992), for example, have argued that openness affects the speed and efficiency with which small countries can absorb technological innovations developed in the industrial world. This idea, based on an insight first proposed by John Stuart Mill, implies that countries with a lower level of trade distortions will experience faster growth in total factor productivity (TFP) and, with other things given, will grow faster than countries that inhibit international competition. ${ }^{27}$

In recent papers a number of authors have tried to test the general implications of these

${ }^{25}$ Of course, this amounts to the important textbook notion that freer trade increases the level of domestic welfare. However, modern approaches go beyond this goal and also consider the acceleration of growth as a goal of trade policy (see Edwards, 1992c).

${ }^{26}$ Traditional neoclassical growth models concentrated on the effect of national economic policies on the level of income per capita. The new generation of endogenous growth models have shifted the attention to relationship between different policies and the rate of growth of the economy. See Lucas (1988).

${ }^{27}$ In chapter 17 of his Principles of Political Economy (1848) Mill said that "a country that produces for a larger market than its own can introduce a more extended division of labor, can make greater use of machinery, and is more likely to make inventions and improvements in the process of production". Arthur Lewis makes a similar proposition in his 1955 classical book on economic growth. 
theories using cross country data sets. ${ }^{28}$ Although different empirical models have yielded different results, the general thrust of this line of research is that indeed countries with less distorted external sectors appear to grow faster. As Dornbusch (1991) has pointed out recently, openness possibly affects growth not only through one channel, but through a combination of channels, including the introduction of new goods, the adoption of new methods of production, the new organization of industries, the expansion in the number of intermediate goods available, and the conquest of new markets that permit the expansion of exports.

The importance placed by liberalization strategists on the reduction of the anti-export bias has resulted in significant emphasis on the role of exchange rate policy during a trade reform effort. A number of authors have argued that a large devaluation is a crucial first step in a trade reform process. Bhagwati (1978) and Krueger (1978) have pointed out that in the presence of quotas and import licenses a (real) exchange rate depreciation will reduce the rents received by importers, shifting relative prices in favor of export-oriented activities and, thus, reducing the extent of the antiexport bias. ${ }^{29}$

\section{II.1. The Speed and Sequencing of Trade Liberalization Reform}

Two fundamental problems have to be addressed in the transition towards freer trade: first, it is important to determine what is the adequate speed of reform. For a long time analysts argued for gradual liberalization programs (Little et al. 1970, Michaely 1985). The reason for this is that, according to these authors, gradual reforms would give firms time for restructuring their productive processes and, thus, would result in low dislocation costs in the form of unemployment and bankruptcies. These reduced adjustment costs would, in turn, provide the needed political support for the liberalization program. Recently, however, the gradualist position has been under attack. There is increasing agreement that slower reforms tend to lack credibility, inhibiting firms from actually engaging in serious restructuring. Moreover, the experience of Argentina in the 1970s has shown that a gradual (and preannounced) reform allows those firms negatively affected by it to (successfully) lobby against the reduction in tariffs. According to this line of reasoning, faster reforms are more

${ }^{28}$ See Tybout (1992) for a general survey on empirical models on the relationship between trade orientation and growth of total factor productivity. See also Edwards (1992c) and de Gregorio (1992).

${ }^{29}$ See Krueger $(1978,1981)$ and Michaely et al (1991). 
credible, and thus tend to be sustained through time (Stockman, 1982).

The thinking on the speed of reform has also been influenced by recent empirical work on the short run unemployment consequences of trade liberalization. Contrary to conventional wisdom, a World Bank study directed by Michaely et al. (1991) on liberalization episodes in 19 countries strongly suggests that, even in the short run, the costs of reform can be small. Although contracting industries will release workers, those expanding sectors positively affected by the reform process will tend to create a large number of employment positions. The Michaely et al. (1991) study shows that in sustainable and successful reforms the net effect-that is the effect that nets out contracting and expanding sectors-on short run employment has been negligible.

The second problem that has to be addressed when designing a liberalization strategy refers to the sequencing of reform (Edwards, 1984). This issue was first addressed in the 1980s in discussions dealing with the Southern Cone (Argentina, Chile and Uruguay) experience, and emphasized the macroeconomic consequences of alternative sequences. It is now generally agreed that resolving the fiscal imbalance and attaining some degree of macroeconomic reform is a priority in implementing a structural reform. Most analysts also agree that the trade liberalization reform has to precede the liberalization of the capital account, and that financial reform cannot be implemented before a modern and efficient supervisory framework is in place. ${ }^{30}$

The behavior of the real exchange rate is at the heart of this policy prescription. The central issue is that liberalizing the capital account would, under some conditions, result in large capital inflows and in an appreciation of the real exchange rate (McKinnon, 1982; Edwards, 1984; Harberger, 1985). ${ }^{31}$ The problem with this is that an appreciation of the real exchange rate sends the "wrong" signal to the real sector, frustrating the reallocation of resources called for by the trade reform. The effects of this real exchange rate appreciation will be particularly serious if, as argued by McKinnon (1982) and Edwards (1984), the transitional period is characterized by "abnormally" high capital inflows that result in temporary real appreciations. If, however, the opening of the capital account is postponed, the real sector will be able to adjust and the new allocation of resources

${ }^{30} \mathrm{Lal}$ (1985) presents a dissenting view. Hanson (1992) has argued that under some circumstances the capital account should be liberalized early on. See chapter 7 for a discussion on sequencing issues with financial reform.

31 This would be the case if the opening of the capital account is done in the context of an overall liberalization program, where the country becomes attractive for foreign investors and speculators. 
will be consolidated. According to this view, this is the right time to liberalize the capital account.

More recent discussions on the sequencing of reform have expanded the analysis, and have included other markets. An increasing number of authors has argued that the reform of the labor market-and in particular the removal of distortions that discourage labor mobility-has to be dealt with before the trade reform and the relaxation of capital controls are implemented. As is argued by Edwards (1992b) it is even possible that the liberalization of trade in the presence of highly distorted labor markets will be counterproductive, generating overall welfare losses in the country in question. Interestingly enough, the discussions on the sequencing of reform have only addressed in detail the proper order in which the liberalization of various "real" sectors in society has to proceed. For instance only a few studies, such as Krueger (1981) and Edwards (1984), have dealt with the order of reform of agriculture, industry, government (privatization), financial services, and education. The key question here, is the extent to which independent reforms will bear all their potential fruits, or whether the existence of synergism implies that in a broad based liberalization process the reforms in different sectors reinforce each other. ${ }^{32}$

As the preceding discussion has suggested real exchange rate behavior is a key element during a trade liberalization transition. According to traditional manuals on "how to liberalize", a large devaluation constitutes the first step in a trade reform process. Maintaining a depreciated and competitive real exchange rate during a trade liberalization process is also important in order to avoid an explosion in imports growth and a balance of payments crisis. Under most circumstances a reduction in the extent of protection will tend to generate a rapid and immediate surge in imports. On the other hand, the expansion of exports usually takes some time. Consequently, there is a danger that a trade liberalization reform will generate a large trade balance disequilibrium in the short run. This, however, will not happen if there is a depreciated real exchange rate that encourages exports and helps maintain imports in check.

Many countries have historically failed to sustain a depreciated real exchange rate during the transition. This has mainly been the result of expansionary macroeconomic policies that generate speculation, international reserves losses and, in many cases, in the reversal of the reform effort. In the conclusions to the massive World Bank project on trade reform Michaely et al (1991) succinctly

${ }^{32}$ Of course, this discussion is related to second best analysis of policy measures. See Edwards (1992b) for a formal multisector model to analyze the welfare consequences of alternative reform packages. 
summarizes the key role of the real exchange rate in determining the success of liberalization programs: "The long term performance of the real exchange rate clearly differentiates "liberalizers" from "non-liberalizers" (p. 119). Edwards (1989e) used data on 39 exchange rate crises and found that in almost every case, real exchange rate overvaluation ended up drastic increases in the degree of protectionism.

\section{II.2 The Order of Stabilization and Trade Liberalization Policies}

The question of the sequencing between macroeconomic stabilization and structural reform especially trade reform - has recently become an important policy issue in a number of places, including Latin America, Eastern Europe and the former Soviet Union. Analysts asked whether fiscal reform should precede structural reform, or whether both types of policies should be implemented simultaneously. By the late 1980 most analysts began to agree that in countries with serious macroeconomic imbalances the most appropriate sequencing required early and decisive action on the macroeconomic front, including solving the "debt-overhang" problem. ${ }^{33}$ It was argued that the reason for this was that the uncertainty associated with very high inflation, including high relative price variability, would reduce the effectiveness of market-oriented structural reforms, and especially of trade liberalization policies. In particular, this high degree of uncertainty would result in low investment and, in some cases, could even direct investment towards the "wrong" sectors (Fischer 1986).

A second argument for the "stabilization first" sequencing refers to the contribution of foreign trade taxes to public revenues. It has been argued that if the public finances have not been brought under control, the reduction of import tariffs would make things worse by increasing the fiscal deficit. This argument is considered to be particularly valid for low income countries, that rely very heavily on taxes on international trade.

As in the case of trade vs. capital account liberalization, the real exchange rate is at the center of the debate. Under a set of (very) plausible conditions macroeconomic stabilization programs will tend to result in an appreciation of the real exchange rate while, as pointed out above, a successful trade reform will require a real depreciation.

A limitation of the "stabilization first" view discussed above is that it does not distinguish

33 See Edwards (1992a) for an account of the sequencing debates. For early discussions see Edwards (1984) and Fischer (1986). 
between different degrees of macroeconomic disequilibria at the time the reforms are initiated. While the relative price variability and real exchange appreciation arguments are eminently plausible for very high inflationary cases, they are unlikely to be too important in countries that start from moderate inflation. For example, Krueger (1981) has argued that the Asian and Middle Eastern experiences suggest that there is very little connection between the determinants of inflation and the orientation of the trade regime. Along similar lines, Edwards (1992) has argued that in countries with moderate rates of inflation trade liberalization and macro stabilization will tend to reinforce themselves. In particular, the reduction of import tariffs and the exposure of the domestic industry to foreign competition will tend to introduce "price discipline". Moreover, the increase in productivity growth usually associated with trade reforms will tend to offset (mild) real exchange rate appreciations that take place during the stabilization effort. A second limitation of the "stabilization first" view is that it tends to ignore the political economy of reform. Two points are in order regarding this issue. First, when embarked in a major transformation process, reform-prone policy makers tend to take advantage to whatever opportunity they have. Second, in many cases it is easier to attack the protectionist lobby - which is fairly well defined and concentrated in specific industries - , than dealing with the interest groups that lead to fiscal imbalances and inflation.

In spite of these limitations the "stabilization first" approach has become the dominant view among policy analysts, including the staff of the multilateral financial institutions such as the World Bank and the International Monetary Fund. However, as is documented in Edwards (1994) almost every country in Latin America ignored this piece of advice, and either embarked on trade reform first, or implemented trade liberalization and stabilization policies simultaneously.

\section{3 The Determinants of Successful Trade Liberalization Policies}

Two economic aspects of trade liberalization are particularly important for analyzing the political economy of transition, and the likelihood of reforms to be sustained through time. First, it has to be recognized that it takes some time for the structural reforms to bear fruit. This means that even though in the long run the reforms will have a positive effect on the aggregate economy, there will be some costs in the short run. These transitional costs, however, will not be even and will affect some groups more heavily than others. Second, even in the long run some groups will lose and will see their real incomes diminished. These groups will be those that have benefitted from the prereform maze of regulations and, in most cases, will tend to oppose the reforms from the beginning. Politically, then, trade reforms only survive if they show some benefits early on and if these benefits 
expand gradually, affecting larger and larger segments of society.

The extensive comparative studies by Little et al (1970), Balassa (1971, 1982), Krueger (1978, 1980), Bhagwati (1978) and Michaely et al (1991) have provided abundant evidence on what are the key determinants of a successful trade reform that persists through time, changing the trade structure of a country. These elements can serve as a guide for policymakers who want to implement trade liberalization policies that will be sustained through time. Existing historical evidence suggests that successful (in the sense of sustained) reforms have been characterized, in the short- and medium-run, by at least some of the following elements: ${ }^{34}$

- Exports, and in particular non-traditional exports, expand at a pace that exceeds the historical rate.

- Productivity growth increases at a fast pace, helping generate rapid growth for the economy as a whole.

- The trade balance does not exhibit "unreasonable" deficits. If this is the case the public will be skeptical about the viability of the reform, and will speculate against the domestic currency.

- The overall level of unemployment stays at a relatively low level.

- Real wages exhibit, at least in the medium run, increases. In order for this increase in wages to affect a broad sector of society, trade liberalization and other structural reforms aimed at deregulating and liberalization other sectors of the economy have to be implemented simultaneously.

\section{The Recent Trade Liberalization Reforms in Latin America and the Caribbean}

The pioneer in the Latin American trade liberalization process was Chile, which between 1975 and 1979 unilaterally eliminated QRs and reduced import tariffs to a uniform level of $10 \%$. After a brief interlude with higher tariffs (at the uniform level of 35\%) by 1992 Chile had reduced its degree of protection to a uniform tariff of $11 \%$ and no licenses or other forms of quantitative controls. Uruguay implemented a reform in 1978, and after a brief reversal, push forward once again in 1986. Bolivia and Mexico embarked on their reforms in 1985-86, followed by a series of countries in the late 1980s. By early 1992 a number of Latin American nations, including Brazil, were proceeding

${ }^{34}$ These elements have been present in most sustained reforms studied in recent times. See, for example, Little et al (1970), Krueger (1978), and Michaely et al (1991) for extensive case studies. 
steadily with scheduled rounds of tariff reduction and the dismantling of quantitative restrictions. However, at the time of this writing it is still unclear whether all these reforms will be sustained, becoming a permanent feature of the Latin economies, or whether some of them will be reversed. Recent developments in Argentina and Colombia indeed suggest that in some countries higher tariffs may be implemented, once again, in the near future.

The Latin American trade reforms have been characterized by four basic elements: (1) The reduction of the coverage of non-tariff barriers, including quotas and prohibitions; (2) The reduction of the average level of import tariffs; (3) The reduction of the degree of dispersion of the tariff structure; (4) The reduction of export taxes. These measures have generally been supported by exchange rate policies aimed at maintaining a competitive real exchange rate. In this section, the extent of the recent liberalization programs is discussed. Section IV deals with the effects of the reform and provide a preliminary evaluation on how these reforms have affected productivity growth and exports expansion. ${ }^{35}$ Section $V$, on the other hand, deals with integration schemes and with the recent evolution of industrial countries' commercial policy with respect to Latin American exports.

\section{I Non-Tariff Barriers}

A key component of the trade reform programs has been the elimination, or at least the severe reduction, of non-tariff barriers (NTBs) coverage. During the early and mid-1980s in some countries, such as Colombia and Peru, more than $50 \%$ of import positions were subject to licenses or outright prohibitions. In Mexico NTBs coverage reached almost 100\% of import categories in 1984, as was the case in most of Central America in 1984 (Table 1).

Table 2 contains data on protectionism in 1985-87 and 1991-92, and shows that in almost every country the coverage of NTBs has been very substantially reduced. ${ }^{36}$ In fact, in a number of cases NTBs have been fully eliminated. The process through which NTBs have been eased has varied

${ }^{35}$ Portions of this section partially draw on Edwards (1992a).

${ }^{36}$ These are unweighted averages, and thus are not comparable to those presented on Table 5.1. There has been a long discussion in applied international trade theory on whether tariffs and NTBs should be measured as weighted or unweighted averages. Both views have some merits and some limitations. An obvious problem of the weighted average approach (where the weights are the import shares) is that more restrictive distortions will tend to have a very small weight. In the extreme case, prohibitive tariffs that effectively ban the importation of a particular item will have a zero weight! Corden (1966) provides an early, and still highly relevant discussion on these issues. 


\begin{tabular}{|c|c|c|c|c|c|}
\hline & s & 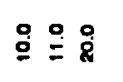 & 品음 & ㅇํำ & 8 \\
\hline & $\frac{2}{3}$ & $\because \cong 8$ & $\because \because$ & 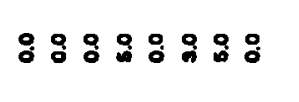 & \\
\hline & $\$$ & | & $\underline{10}$ & 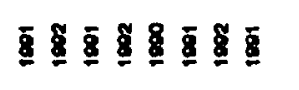 & 8 \\
\hline$\underline{\underline{z}}$ & $\underline{z}$ & 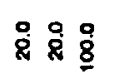 & 然里 & 量最 & \\
\hline & $\frac{2}{\frac{2}{2}}$ & $\because \because$ & $\because \because$ & $88: 99888$ & \\
\hline & 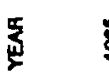 & 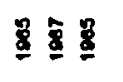 & 8 & 898989 & \\
\hline
\end{tabular}

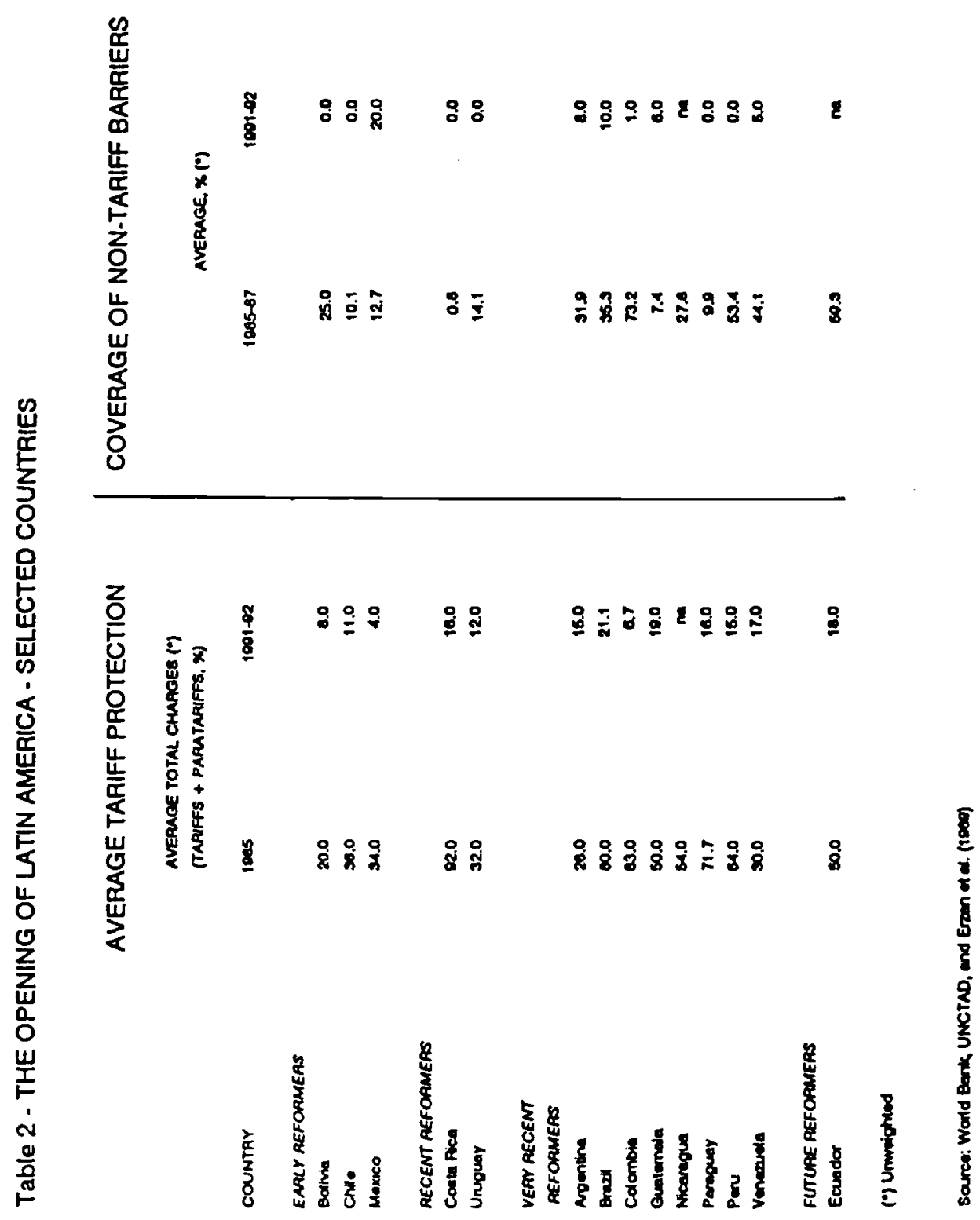


from country to country. In some cases, such as Honduras, they were initially replaced by (quasi) equivalent import tariffs, and then slowly phased out. In other countries, like Chile, NTBs were eliminated rapidly without a compensating hike in tariffs.

As Table 2 shows, in spite of the progress experienced in the last few years, significant NTB coverage remains in a number of countries. In most cases these non-tariff barriers correspond to agricultural products. For example, in Mexico approximately $60 \%$ of the agriculture's sector tariff positions were still subject to import licenses in mid-1992 - scheduled to be eliminated with respect to U.S. imports as a result of NAFTA. An important feature of the region's liberalization programs is that they have proceeded much slower in agriculture than in industry. This has largely been the result of the authorities desire to isolate agriculture from fluctuations in world prices, and unfair trade practices by foreign countries. ${ }^{37}$ However, as a recent study by Valdes (1992), has shown this approach based on quantitative restrictions entails serious efficiency costs. Slowly, however, more and more countries are addressing these concerns by replacing quantitative restrictions by variable levies, and by introducing a system for smoothing price fluctuations based on price bands. ${ }^{38}$

\section{2 Tariff Dispersion}

The import substitution development strategy pursued for decades in Latin America created highly dispersed protective structures. According to the World Bank (1987), Brazil, Chile and Colombia had some of the highest degrees of dispersion in effective protection in the world during the 1960s. Also, Heitger (1987) shows that during the 1960 s Chile had the highest rate of tariff dispersion in the World-with a standard deviation of $634 \%$-closely followed by Colombia and Uruguay. Cardoso and Helwege (1991) have pointed out that highly dispersed protective structures generate high welfare costs, by increasing uncertainty and negatively affecting the investment process. These highly dispersed tariffs and NTBs were the result of decades of lobbying by different sectors to obtain preferential treatment. As the relative power of the different lobbies changed, so did their

${ }^{37}$ The issue of protecting local producers from "dumping" is an important one in the design of the new liberalized trade regimes. The crucial problem is to enact legislation that is able to distinguish true cases of unfair trade practices from simple cases of increased foreign competition stemming from more efficient productive processes. At this time the approval of a dynamic and flexible anti-dumping legislation should be high in the region's agenda for legal and institutional reform.

${ }^{38}$ See Valdes (1992). 
tariff concessions and the protective landscape.

An important goal of the Latin trade reforms has been the reduction of the degree of dispersion of import tariffs. Table 2 contains data on the tariff range for a group of countries for two points in time-mid-1980s (1985-87) and 1991-92-and clearly documents the fact that the reforms have indeed reduced the range between minimum and maximum tariffs. In many cases this has meant increasing tariffs on goods that were originally exempted from import duties. In fact, this Table shows that in many countries the minimum tariff was zero percent in the mid-1980s. Generally, zero tariffs have been applied to intermediate inputs used in the manufacturing process. ${ }^{39}$ From a political economy perspective the process of raising some tariffs, while maintaining a proliberalization thetoric, has not always been easy. Those sectors that had traditionally benefitted from the exemptions tried to oppose them strongly as they suddenly saw their privileged situation coming to an end.

An important question addressed by policymakers throughout the region refers to the extent of reduction in tariff dispersion. Should the reforms implement a uniform tariff, or is some (small) degree dispersion desirable? Although from a strict welfare perspective uniform tariffs are only advisable under very special cases, they have a strong administrative and political-economy appeal. In particular, a uniform tariff system is very transparent, making it difficult for the authorities to grant special treatments to particular firms or sectors (Harberger, 1990).

\section{3 Average Tariffs}

Reducing the average degree of protection is, perhaps, the fundamental policy goal of trade liberalization reforms. Traditional policy manuals on the subject suggest that once the exchange rate has been devalued and quantitative restrictions have been reduced or eliminated, the next step is to

${ }^{39}$ This system with very low (or zero) tariffs on intermediate inputs and high tariffs on final goods generated very high rates of effective protection or protection to domestic value added. In recent years a number of authors have argued that the use of effective protection is misleading. The reason for this is that ERPs are unable to provide much information on the general equilibrium consequences of tariff changes (Dixit, 1986). In spite of this, ERP measures are still useful, since they provide an indication on the degree of "inefficiency" a country is willing to accept for a particular sector. 
slash tariffs in such a way that both their range and average are reduced. ${ }^{40}$ Table 2 contains data on average total tariffs (tariffs plus paratariffs) in 1985 and 1991-92. As can be seen, the extent of tariff reduction has been significant in almost every country. Even nations that have acted somewhat cautiously on the reform front, have experienced important cuts in import tariffs, allowing a more competitive environment and reducing the degree of anti-export bias of the trade regime.

Countries that have embarked on trade liberalization in recent years have moved at a much faster speed than those nations that decided to open up earlier. There has, in fact, been a clear change in what is perceived to be abrupt and rapid removal of imports impediments. What only 15 years ago were seen as brutally fast reforms, are now looked at as mild and gradual liberalizations. When Chile initiated the trade reform in 1975 most analysts thought that the announced tariff reduction from an average of $52 \%$ to $10 \%$ in four and a half years was an extremely aggressive move that would cause major dislocations, including large increases in unemployment. The view on the speed of reform has become very different in the early 1990s, when an increasing number of countries have been opening up their extemal sectors very rapidly. For instance, Colombia slashed (total) import tariffs by $65 \%$ in one year, reducing them from $34 \%$ in 1990 to $12 \%$ in 1991 . This fast approach to liberalization has also been followed by Argentina, Peru and Nicaragua. This latter country eliminated quantitative restrictions in one bold move and slashed import tariffs from an average of $110 \%$ in 1990 to $15 \%$ in March of 1992.

\section{III.4 Exchange Rate Policy}

In the vast majority of countries the first step in the recent trade reform process was the implementation of large (nominal) devaluations. In many cases this measure represented a unification of the exchange rate market. Most countries implemented large exchange rate adjustments as early as 1982 in order to face the urgencies of the adjustment process. The purpose of these policies was to generate real exchange rate devaluations, as a way to reduce the degree of anti-export bias of incentives systems.

Many countries adopted crawling peg regimes, characterized by a periodic small devaluation

\footnotetext{
${ }^{40}$ However, "tariffs" is sometimes a misleading term, since many countries have traditionally relied on both import duties (that is tariffs proper) and import duty surcharges or paratariffs. See Harberger (1992) for a discussion on the actual mechanics for reducing uneven tariffs.
} 
of the nominal exchange rate, as a way to protect the real exchange rate from the effects of inflation. ${ }^{41}$ Table 3 contains data on real exchange rates for a group of Latin American countries for 1980, 1987 and 1992. Once again, an increase in the index represents a real exchange rate depreciation and thus an improvement in the degree of competitiveness. Between 1980 and 1987 almost every country in the sample experienced very large real depreciations (see Edwards, 1994). In many cases, however, these have been partially reversed in the last few years. This has been the consequence of a combination of factors, including the inflow of large volumes of foreign capital into these countries since 1990, and the use of the exchange rate as the cornerstone of the disinflation policies. This is addressed in Section IV of this paper. Overall, however, in most countries the real exchange rate was depreciated significantly more by late 1991 than in 1981 . This greatly encouraged exports, helping revert decades of discriminatory policies.

\section{The Effects of Trade Liberalization}

The trade liberalization reforms implemented in Latin America had three fundamental objectives: (a) to reduce the anti-export bias of the old regime and, thus, to encourage exports; (b) to help create an increase in total factor productivity growth through greater competition and enhanced efficiency; and (c) to increase consumer welfare by reducing the real prices of importable goods. In this section the evolution of productivity and exports in the post-reform period are analyzed in some detail.

\section{IV.I Trade Liberalization and Productivity Growth}

The relaxation of trade impediments has had a fundamental impact on the region's economies. Suddenly, Latin America's industry, which to a large extent had developed and grown behind protective walls, was forced to compete. Many firms have not been able to survive this shock and have become bankrupt. Others, however, have faced the challenge of lower protection by embarking on major restructuring and increased their level of productivity.

The ability (and willingness) of firms to implement significant adjustment depends on two main factors: the degree of credibility of the reform and the level of distortions in the labor market.

\footnotetext{
${ }^{41}$ Some countries, most notably Brazil, Chile and Colombia, experimented with crawling pegs as early as the 1960s. However, only Colombia maintained a regime that avoided real exchange rate overvaluation.
} 


\section{Table 3 - REAL EXCHANGE RATES IN SELECTED LATIN AMERICAN COUNTRIES (a) $(1985=100)$}

$\begin{array}{lrrrrr}\text { COUNTRY } & 1980 & 1983 & 1987 & 1992 & 1993 \text { (b) } \\ \text { Argentina } & & & & & \\ \text { Bolivia } & 35.8 & 96.4 & 80.8 & 36.9 & 34.0 \\ \text { Brazil } & 88.1 & 84.6 & 107.9 & 109.6 & 113.3 \\ \text { Chile } & 70.7 & 88.7 & 78.0 & 51.7 & 45.7 \\ \text { Colombia } & 55.3 & 75.3 & 94.8 & 75.1 & 75.2 \\ \text { Costa Rica } & 79.2 & 78.3 & 115.9 & 119.9 & 102.6 \\ \text { Ecuador } & 65.8 & 103.0 & 94.9 & 88.2 & 82.9 \\ \text { El Salvador } & 105.6 & 104.5 & 153.3 & 165.7 & 153.9 \\ \text { Guatemala } & 172.6 & 133.9 & 121.0 & 103.7 & n a \\ \text { Honduras } & 124.9 & 120.5 & 162.0 & 149.5 & n a \\ \text { Jamaica } & 121.6 & 106.2 & 93.2 & 141.5 & 152.3 \\ \text { Mexico } & 60.1 & 54.8 & 80.1 & 94.5 & 70.7 \\ \text { Panama } & 83.3 & 119.8 & 123.9 & 68.7 & 63.8 \\ \text { Paraguay } & 102.0 & 100.7 & 98.8 & 107.8 & 106.5 \\ \text { Peru } & 74.4 & 60.7 & 111.4 & 113.0 & \text { na } \\ \text { Trinidad and Tobago } & 152.9 & 117.3 & 122.8 & 112.1 & 129.0 \\ \text { Uruguay } & 49.7 & 89.4 & 77.2 & 55.5 & 40.5 \\ \text { Venezuela } & 84.2 & 70.3 & 134.8 & 122.3 & 119.1\end{array}$

(a) Increases indicate currency depreciation against the US\$.

(b) Preliminary.

Source: Calculated using data from the International Financial Statistics database, IMF. 
If entrepreneurs believe that the reform will not persist through time, there will be no incentives to incur the costs of adjusting the product mix and of increasing the degree of productive efficiency. In fact, if the reform is perceived as temporary, the optimal behavior is not to adjust; instead it is profitable to speculate through the accumulation of imported durable goods. This was, as Rodriguez (1982) has documented, the case in Argentina during the failed Martinez de Hoz's reforms. ${ }^{42}$ In their studies on the interaction between labor markets and structural reforms Krueger (1980) and Michaely et al. (1991) found that most successful trade reforms have indeed resulted in major increases in labor productivity. In most cases where this has happened labor markets have been characterized by some degree of flexibility. Countries with rigid and highly distorted labor markets-including countries with high costs of dismissal, limitations on temporary contracts and rigid minimum wage legislation-have generally exhibited modest improvements in labor productivity after the trade reform process.

Some of the early Latin American reformers have experienced important labor productivity improvements. For example, according to Edwards and Edwards (1991) labor productivity in the Chilean manufacturing sector increased at an average annual rate of $13.4 \%$ between 1978 and 1981 . The available evidence also suggests that the increases in labor productivity in the Mexican manufacturing sector in the post reform period has been significant. According to Sanchez (1992), labor productivity in Mexico's manufacturing sector increased at an annual rate of almost $4 \%$ between 1986 and 1991. This figure is more than double the historical annual rate of growth of labor productivity in the manufacturing sector between 1960 and 1982-1.6\% (Elias, 1992).

As discussed above, recent models of growth have suggested that countries that are more open to the rest of the world will exhibit a faster rate of technological improvement and productivity growth than countries that isolate themselves from the rest of the world. From an empirical point of view, this means that countries that open up their external sectors and engage in trade liberalization reforms will experience an increase in total factor productivity growth relative to the pre-reform period. The empirical analysis presented in Edwards (1992) supports the idea that, when other variables (such as human capital formation, government size, political volatility and the development gap) are held constant, the degree of openness of the economy is positively associated with the rate of growth of productivity. What is particularly important is that this result appears to be robust to the

${ }^{42}$ See Corbo et. al. (1985) for a detailed microeconomic account of the process of adjustment in a large group of Chilean manufacturing firms. 
proxy used to measure trade policy orientation.

Table 4 contains data on the change in aggregate total factor productivity growth in the period following the implementation of trade liberalization reform in six Latin Countries. ${ }^{43}$ Although these data cannot be interpreted as capturing causality, they are still suggestive. As can be seen, Chile and Costa Rica, two of the earlier reformers, experienced very large increases in TFP growth in the post reform period. The results for Chile coincide with those obtained by Edwards (1985), who found that in the late 1970s, after the trade reforms had been completed, TFP growth was approximately three times higher than the historical average. ${ }^{44}$ Although the outcome has been less spectacular, Argentina and Uruguay still exhibit important improvements in productivity growth in the period following the opening up. Bolivia, on the other hand, presents a flat profile of TFP growth.

Sturzenegger (1992) argues that the very slow improvement in Bolivian productivity growth has been, to a large extent, the result of negative terms of trade shocks and, in particular, the collapse of the tin market. ${ }^{45}$

Perhaps the most puzzling result in Table 4 is the slight decline in aggregate TFP growth in Mexico after the reforms. Martin (1992) shows that this finding is robust to alternative methods of measuring TFP growth, including different procedures for correcting for capacity utilization. Also, Harberger (1992) has found a slowing down of TFP growth in Mexico in 1986-90 relative to 1975-

\footnotetext{
${ }^{43}$ The original TFP growth data comes from Martin's (1992) study on sources of growth in Latin America. The countries in Table 5.4 are those that initiated the reform before 1988. In order to compute series on TFP growth Martin (1992) analyzed the contributions of capital and labor, and explicitly incorporated the role of changes in the degree of capital utilization. The countries considered in this study are: Argentina, Bolivia, Chile, Colombia, Costa Rica, Dominican Republic, El Salvador, Guatemala, Honduras, Mexico, Nicaragua, Panama, Peru, Uruguay and Venezuela. Harberger (1992) presents data on TFP growth before and after a series of historical trade reform episodes. He finds that in the majority of the cases productivity growth increased after the liberalization process.

${ }^{44}$ It may be argued, however, that the major increase in TFP growth in Chile has been the result of the complete structural reform package implemented in that country.

${ }^{45}$ In a series of recent studies Ocampo (1991) has calculated total factor productivity growth in Colombia. He found that the increase in protectionism in 1982-85 was accompanied by a decline in productivity growth.
} 


\title{
Table 4 - CHANGES IN TOTAL FACTOR PRODUCTIVITY GROWTH
}

\author{
Percentages
}

Argentina

1.91

Bolivia

0.11

Chile

4.96

Costa Rica

3.25

Mexico

$-0.32$

Uruguay

2.02

For all countries but Chile, computed as the difference of TFP growth for 1987-91 and 1978-82. For Chile the pre-reform period is 1972-78.

Source: Martin (1992) 
82. ${ }^{46}$ However, the aggregate nature of the TFP growth data in Table 4 tends to obscure the actual sectoral response to trade reform in Mexico. According to new theories on endogenous growth, faster productivity will be observed in those sectors where protectionism has been reduced and not in those still subject to trade barriers or other forms of regulation.

A distinctive characteristic of the Mexican reform is that, contrary to the Chilean case, it proceeded at an uneven pace. In particular, while most of the manufacturing sector-with the exception of automobiles - experienced early on a significant reduction in protection, agriculture continues to be subject to relatively high tariffs and substantial nontariff barriers. Moreover, until very recently the Mexican land tenure system was subject to a legal system that, among other things, severely restricted the market for land and distorts economic incentives in many other directions-the Ejido system. Although most agricultural sector regulations were legally eliminated in early 1992 , these reforms still have to have a practical impact. The reason for this is that the titling process, where property rights are actually assigned, is only in its infancy; by mid-1993 practically no ejidos have yet been converted into private landholdings. ${ }^{47}$ Also, during much of the post-debt crisis period large fragments of services sector in Mexico-including telecommunications and financial services-were under direct government control and subject to distortions.

Table 5 contains data on TFP growth in Mexico's manufacturing sector for 1940-89.48 Interestingly enough, these figures indicate that in the post-trade reform period the rate of productivity growth in the Mexican manufacturing sector has exceeded every subperiod since 1940 for which there are data. This provides evidence in favor of the view that, once the sectors actually subject to increased competition are considered, Mexican productivity growth has indeed improved after the trade reform. This proposition is supported by results recently obtained by Weiss (1992), who used regression analysis to investigate the impact of the trade reforms on productivity and cost margins.

${ }^{46}$ However, according to Harberger's data, TFP growth in $1986-90$ exceeds the level of immediate post-crisis years. The actual TFP growth numbers calculated by Harberger are the following: $1950-60=3.8 ; 1960-75=3.9 ; 1975-82-2.5 ; 1982-86=-2.8 ; 1986-90=$ 0.8 . An important difference between the Martin and Harberger computations is that the former does not make corrections for different degrees of capacity utilization.

${ }^{47} \mathrm{~A}$ number of observers have argued that the titling process will, by itself, take between five and ten years.

${ }^{48}$ Since these figures come from two different sources they may not be fully comparable and, thus, should be interpreted with care. 


\title{
Table 5 - TOTAL FACTOR PRODUCTIVITY GROWTH IN MANUFACTURING IN MEXICO: 1940-1990
}

\author{
Manufacturing \\ TFP Growth \\ (percentage) \\ $1940-50$ \\ $1950-60$ \\ $1960-70$ \\ $1970-80$ \\ $1985-89$ \\ 0.46 \\ 0.53 \\ 3.00 \\ ก.a. \\ 3.40 \\ Sources: The data for $1940-80$ are from Ellas (1992). The figure \\ for $1985-89$ is from lbarra (1992).
}


An important question in evaluating the effects of trade reform refers to the speed with which productivity growth will react to the new incentives. Will the response be rapid, or will it be necessary to wait for a long period of time before seeing the fruits of the reforms? Existing data for the case of Chile provides some support for the idea that total factor productivity growth will react quite fast. For example, Edwards (1985) found that already by 1979-the year the trade reform reached its goal of a uniform $10 \%$ import tariff-aggregate total factor productivity growth in Chile had reached $5.4 \%$, significantly higher than the historical level. More recently, Agacino et al. (1992) have found that total factor productivity growth averaged $3.9 \%$ per year during 1976-81, greatly exceeding the historical average of approximately $1 \%$. These authors also found that there had been significant variations across industries, during 1976-81. In some cases average productivity growth exceeded the $10 \%$ annual mark-wood products, glass industries-while in others it was negative-non-electric machinery, for example.

\section{IV.2. Trade Reforms and Exports}

An important goal of the trade reforms has been to reduce the traditional degree of anti-export bias of Latin American trade regimes and to generate a surge in exports. In fact, based on the East Asian model, Latin American leaders have increasingly called for the transformation of the external sector into the region's "engine of growth". As pointed out previously, it is expected that the reduction of the traditional anti-exports bias will take place through three channels: a more competitive-that is more devalued-real exchange rate; a reduction in the cost of imported capital goods and intermediate inputs used in the production of exportable; and a direct shift in relative prices in favor of exports.

The volume of international trade in Latin America, and in particular the volume of exports, increased significantly after the reforms were initiated. ${ }^{49}$ For example, while the volume of exports for the region as a whole grew at an annual rate of only $2.0 \%$ between 1970 and 1980, it grew at a rate of $5.5 \%$ between 1980 and 1985 and at an annual average of $6.7 \%$ between 1986 and 1990 . The real value of exports, however, has evolved at a somewhat slower pace. The reason for this is that

${ }^{49}$ Trade liberalization aims at increasing a country's total volume of trade. Under textbook conditions it is expected that at the end of the reform trade will be balanced. However, there are a number of circumstances, including the need to pay the country's foreign debt, under which trade will not grow in a balanced way after a reform. This has been the case in the majority of the Latin American Countries. 
terms of trade have experienced, in every subgroup of countries, a significant deterioration during 1980-93 (see CEPAL 1993). Although, strictly speaking, it is not possible to attribute this export surge fully to the opening up reforms, there is significant country-specific evidence suggesting that a more open economy, and in particular a more depreciated real exchange rate, has positively affected exports growth. ${ }^{50}$ Some countries, especially Costa Rica, have accompanied the opening process with the implementation of a battery of export promotion schemes, including tax credits-through the "Certificado de Abono Tributario"-duty free imports and income tax exemptions. However, some authors, including Nogues and Gulati (1992), have argued that these systems have been fiscally expensive and have not been an effective way of encouraging exports. ${ }^{51}$

Table 6 presents detailed country level data on the rate of growth of the total value of exports (in constant dollars) for three different periods. Table 7, on the other hand, contains information on the evolution of exports volume throughout the period. A number of facts emerge from these tables. First, while there has been a rapid growth in exports for the region as a whole, there are nontrivial variations across countries; in some cases there has even been a decline in the real value of exports-this is the case, for example, of Peru. Second, exports performance during the two subperiods (1982-87 and 1987-92) has not been homogeneous. In the majority of the countries exports performed significantly better during 1987-92, than in the previous five years reflecting, among other things, the fact that it takes some time for exports to actually respond to greater incentives.

An interesting fact that emerges from these tables is that in the country that has lagged behind in terms of trade reform - Ecuador - the performance of exports volume has been, in the recent years, below the 1970-80 historical average. On the other hand, in two of the early reformers Bolivia and Chile - exports have had a very strong behavior in the 1987-90 subperiod.

The case of Chile is particularly interesting. Since most of its liberalization effort was undertaken prior to 1980 , there are enough data points as to provide a more detailed evaluation of export response to the new regime. Between 1975 and 1980 - when tariffs were reduced to a uniform 10\% and NTBs were completely eliminated - the behavior of Chilean exports was

${ }^{50}$ See, for example, Nogues and Gulati (1992).

${ }^{51}$ This, however, remains a controversial issue. Some authors (Sachs, 1987), for example, have pointed to the Korean experience to suggest that government policies in support of exports may be beneficial. For a brief account of the Korean experience, see chapter 3 . 


\section{Table 6 - GROWTH IN VALUE OF EXPORTS OF GOODS AND NON-FACTOR SERVICES (Annual percentage growth rates at constant prices)}

\begin{tabular}{|c|c|c|c|c|c|c|c|}
\hline & $1970-80$ & $1982-87$ & 1987.92 & 1991 & 1992 & 1993 & $\begin{array}{c}\text { Avg. } \\
\text { (b) } 1991-93\end{array}$ \\
\hline Argentina & 4.8 & -0.1 & 6.6 & -3.0 & 2.1 & 6.3 & 1.8 \\
\hline Bolivia & 0.6 & 0.6 & 8.1 & -8.5 & -20.0 & 3.6 & -8.3 \\
\hline Brazil & 9.9 & 9.7 & 5.5 & 0.7 & 14.2 & 7.7 & 7.5 \\
\hline Chile & 10.2 & 6.5 & 10.9 & 7.4 & 11.9 & -7.7 & 3.9 \\
\hline Colombia & 5.7 & 10.2 & 6.7 & 6.0 & -3.3 & 5.9 & 2.9 \\
\hline Costa Rica & 5.9 & 5.7 & 10.9 & 10.6 & 14.4 & 11.7 & 12.2 \\
\hline Ecuador & 14.0 & 3.3 & 9.1 & 5.0 & 5.5 & -2.8 & 2.6 \\
\hline Mexjco & 8.3 & 5.8 & 3.5 & 0.1 & 2.5 & 6.8 & 3.1 \\
\hline Paraguay & 6.1 & 5.4 & 9.5 & -19.2 & -10.2 & 32.6 & 1.1 \\
\hline Peru & 2.7 & -4.5 & 0.8 & 3.0 & 4.7 & -2.8 & 1.6 \\
\hline Uruguay & 7.2 & 4.2 & 7.1 & -5.2 & 6.1 & -6.0 & -1.7 \\
\hline Venezuela & -7.3 & 3.6 & 4.4 & -14.2 & -6.8 & -0.1 & -7.0 \\
\hline
\end{tabular}

(a) $1974-80$

(b) Preliminary

Source: World Bank 


\section{Table 7 - GROWTH IN VOLUME OF EXPORTS OF GOODS (Annual percentage growth rates)}

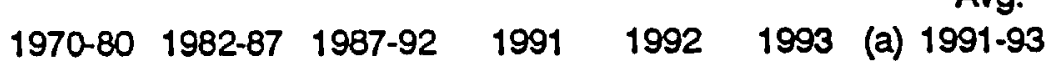

Argentina
Bolivia
Brazil
Chile
Colombia
Costa Rica
Ecuador
Mexico
Paraguay
Peru
Uruguay
Venezuela

$\begin{array}{rrrrrrr}2.1 & 0.8 & 12.8 & -0.5 & -0.6 & 0.8 & -0.1 \\ -1.7 & -5.2 & 13.2 & -4.2 & 3.7 & 16.3 & 5.3 \\ 8.2 & 8.0 & 1.5 & 3.5 & 18.5 & 11.7 & 11.2 \\ 7.4 & 7.6 & 7.4 & 6.6 & 21.8 & 3.1 & 10.5 \\ 3.6 & 14.8 & 7.3 & 19.6 & 7.9 & 10.3 & 12.6 \\ 3.8 & 6.2 & 7.5 & 14.0 & 19.9 & 12.2 & 15.4 \\ 14.6 & 6.8 & 8.2 & 12.7 & 6.7 & 0.7 & 6.7 \\ 10.2 & 6.1 & 5.5 & 10.6 & 7.7 & 7.9 & 8.7 \\ 7.3 & 9.2 & 17.2 & -19.0 & -5.8 & 31.3 & 2.2 \\ 2.3 & -4.0 & 1.3 & -0.9 & 6.0 & 10.4 & 5.2 \\ 5.4 & -0.5 & 4.8 & -0.7 & 6.8 & -7.8 & -0.6 \\ -5.8 & 2.1 & 7.5 & 5.9 & 0.6 & 13.0 & 6.5\end{array}$

(a) Preliminary

Source: CEPAL 
spectacular, growing (in volume terms) at an average of $12 \%$ per year - many times higher than the historical average of $1960-70$ of only $2.6 \%$ per annum. What is particularly impressive is that most of the export surge has taken place in the nontraditional sector (CEPAL, 1991).

The story of Chile's success in the last few years has been closely related to a boom in agriculture, forestry and fishing exports. During the $1960-70$ period Chile was basically a net importer of agricultural goods. Today, on the other hand, agriculture-as well as forestry and fishing-exports are becoming increasingly important in the Chilean economy. In 1970 Chile exported US $\$ 33$ million in agriculture, forestry and fishing products; by 1991 this figure had jumped to US\$1.2 billion! Notice, that this figure excludes those manufactured goods based on the elaboration of the agriculture sector. There is little doubt that economic policy lies behind the stellar behavior of the Chilean agriculture and export sectors in the last few years. First, the liberalization of international trade substantially lowered the costs of agriculture imported inputs and capital goods, making the sector more competitive. In fact, the liberalization of international trade put an end to a long trend of discrimination against agriculture. This, as was pointed out above, contrasts with Mexico, where agriculture has not benefitted yet from the very recent liberalization measures, including the reform of the old ejido system. Second, the exchange rate policy pursued aggressively in Chile since 1985 has provided clear incentives for the expansion of exports. However, as is discussed in some detail in Section V.4, the current trend towards real exchange rate appreciation represents a cloud in the future of the sector. A third fundamental policy-based explanation of the Chilean agriculture success has to do with the pursue of a stable macroeconomic policy. This has allowed entrepreneurs to have confidence in the system and to plan their activities over the longer run. Many of the export-oriented agriculture activities have required sizable investments that are only undertaken in an environment of stability and policy continuity. And fourth, the strict respect for property rights, and the emergence of a stable and legal framework, also had significant, positive effects on the evolution of Chilean agriculture exports.

As Tables 6 and 7 show, Mexico has exhibited a slower rate of growth of total exports in the post reform period than during 1970-80. This, however, is largely an illusion stemming from the fact that during the 1970s Mexico's oil production increased very rapidly-at a rate exceeding $18 \%$ per year. When nontraditional exports are considered the post-reform performance is remarkable with an 
annual average rate of growth for $1985-91$ exceeding $25 \%$ (see Table 8). ${ }^{52}$

After two successive years of decline, the volume of exports increased very rapidly in Brazil during 1992-14.9\%. In 1993 Brazilian exports expanded, in volume terms at almost $12 \%$. Although it is too early to tell what are the exact forces behind this rapid growth, and whether it will be sustained, there is some indication that the highly depreciated real exchange rate and the reduction in the degree of protection in the country have helped increase the degree of international competitiveness of Brazil's exports. ${ }^{53}$ This interpretation is supported by recent empirical results by Bonelli (1992) who found that productivity growth in Brazil's manufacturing sector has been positively affected by export orientation.

A stated objective of trade reforms has been to increase the degree of diversification of exports. Table 9 contains data for a large number of countries on the share of manufacturing exports and shows that in the period following the trade reforms their importance has increased steadily in the early reformers-Bolivia, Chile and Mexico. Also, in the majority of the countries, the share of the ten most important export goods in total exports has declined significantly in the last few years (CEPAL, 1991).

A somewhat troublesome recent development is that during 1993 the rate of export growth (measured in constant value) has slowed down significantly in many Latin American countries. This has been the result of a host of factors, including the sluggishness of the world economy, the slowing down of productivity gains and, especially, the recent trends towards real exchange rate appreciation observed in most countries in the region.

\section{Real Exchange Rate Behavior, Capital Inflows and the Future of Trade Reforms in Latin America}

In the last few years, competitive real exchange rates have been at the center of the vigorous performance of most of Latin America's external sectors. In fact, it is not an exaggeration to say that the trade reforms have been driven by highly competitive real exchange rates, making Latin products very attractive in world markets. However, as pointed out previously, in most Latin countries real

\footnotetext{
${ }^{52} \mathrm{~A}$ large percentage of this growth, however, has been in the maquiladora or in-bond sector.

${ }^{53} \mathrm{Also}$, the reduction in internal demand could have affected the recent rapid growth in exports.
} 
Table 8 - NONTRADITIONAL EXPORTS

Nontraditional exports as a share of all exports (percent)

$\begin{array}{llllll}\text { Country } & 1980 & 1982 & 1985 & 1987 & 1991 \\ \text { Argentina } & 0.27 & 0.31 & 0.28 & 0.31 & 0.35 \\ \text { Bolivia } & 0.15 & 0.09 & 0.05 & 0.19 & 0.30 \\ \text { Brazil a/ } & 0.57 & 0.59 & 0.66 & 0.69 & 0.71 \\ \text { Chile } & 0.38 & 0.22 & 0.35 & 0.39 & 0.36 \mathrm{~b} / \\ \text { Colombia } & 0.41 & 0.42 & 0.41 & 0.55 & 0.64 \mathrm{~d} \\ \text { Costa Rica } & 0.36 & 0.38 & 0.37 & 0.42 & 0.50 \\ \text { Ecuador \& } & 0.24 & 0.09 & 0.12 & 0.14 & 0.12 \\ \text { Mexico } & 0.13 & 0.20 & 0.18 & 0.38 & 0.50 \\ \text { Paraguay } & 0.58 & 0.71 & 0.82 & 0.68 & 0.69 \\ \text { Peru } & 0.21 & 0.23 & 0.24 & 0.27 & 0.28 \\ \text { Uruguay } & 0.61 & 0.58 & 0.66 & 0.67 & 0.71 \\ \text { Venezuela } & 0.04 & 0.07 & 0.09 & 0.13 & 0.17\end{array}$

a/ Industrial products.

b/ 1989 data; subsequent data are classified differently.

c/ 1990 data.

d/ Manufactured products.

Source: CEPAL, Economic Survey of Latin America, several issues. 
Table 9 - EXPORTS OF MANUFACTURED GOODS

Manufactured exports as a share of all exports (percent)

$\begin{array}{lllllll}\text { COUNTRY } & 1970 & 1980 & 1982 & 1985 & 1987 & 1991\end{array}$

$\begin{array}{lllllll}\text { Argentina } & 0.14 & 0.23 & 0.24 & 0.21 & 0.31 & 0.28 \\ \text { Bolivia } & 0.03 & 0.02 & 0.03 & 0.01 & 0.03 & 0.05 \mathrm{a} / \\ \text { Brazil } & 0.15 & 0.37 & 0.38 & 0.44 & 0.50 & 0.55 \\ \text { Chile } & 0.04 & 0.09 & 0.07 & 0.11 & 0.09 & 0.11 \\ \text { Colombia } & 0.11 & 0.20 & 0.24 & 0.17 & 0.19 & 0.33 \\ \text { Costa Rica } & 0.19 & 0.28 & 0.25 & 0.22 & 0.24 & 0.25 \\ \text { Ecuador } & 0.02 & 0.03 & 0.03 & 0.01 & 0.02 & 0.02 \\ \text { Mexico } & 0.33 & 0.11 & 0.10 & 0.21 & 0.38 & 0.44 \mathrm{a} / \\ \text { Paraguay } & 0.08 & 0.04 & 0.09 & 0.06 & 0.10 & 0.11 \\ \text { Peru } & 0.01 & 0.17 & 0.16 & 0.13 & 0.17 & 0.19 \mathrm{a} / \\ \text { Uruguay } & 0.15 & 0.38 & 0.32 & 0.35 & 0.55 & 0.52 \\ \text { Venezuela } & 0.01 & 0.02 & 0.02 & 0.10 & 0.06 & 0.11 \mathrm{a}\end{array}$

a/ 1990 data.

Source: CEPAL, Statistical Yearbook for Latin America, several issues. 
exchange rates have recently experienced significant real appreciations and losses in competitiveness.

Figure 1 presents the evolution of real exchange rates for selected countries. As in previous diagrams and tables, an increase (decline) in the real exchange rate index captures a real exchange rate depreciation (appreciation).

These real appreciations (and losses in international competitiveness) have generated considerable concern among policymakers and political leaders ${ }^{54}$ and have been the result of two basic factors: first, a large number of countries are using exchange rate policy as an anti-inflationary tool and, second, recent massive capital inflows into Latin America that have made foreign exchange "overabundant".

Tables 10 and 11 contain data on capital inflows into Latin America and show that, after eight years of negative resource transfers, there has been a significant turnaround in 1991-92. This increased availability of foreign funds has affected the real exchange rate through increased aggregate expenditure. A proportion of the newly available resources has been spent on nontradables-including the real estate sector-putting pressure on their relative prices and on domestic inflation. An interesting feature of the recent capital movements is that a large proportion corresponds to portfolio investment and relatively little is direct foreign investment. As can be seen, Mexico has been the most important recipient of foreign funds in the region in the last years. Indeed it has been this very large availability of foreign financing what has allowed that country to have a current account deficit of the order of 5-6 percent of GDP. An important question, however, is whether this situation will be sustainable through time, or if a decline in the level of funds available is foreseen in the near future.

Real exchange rate appreciations generated by increased capital inflows are not a completely new phenomenon in Latin America. In the late 1970s most countries in the region, but especially the Southern Cone nations, were flooded with foreign resources that led to large real appreciations. The fact that this previous episode ended in the debt crisis has added dramaticism to the current concern about the possible negative effects of these capital flows.

Whether these capital movements are temporary-and thus subject to sudden reversals as in 1982-is particularly important in evaluating their possible consequences. In a recent study, Calvo, Leiderman, and Reinhart (1992) argue that the most important causes behind the generalized inflow of resources are external. In particular, their empirical analysis suggests that the two main reasons

\footnotetext{
${ }^{54}$ See Calvo, et al (1992).
} 
Figure 1

REAL EFFECTIVE EXCHANGE RATES IN SELECTED LATIN AMERICAN COUNTRIES

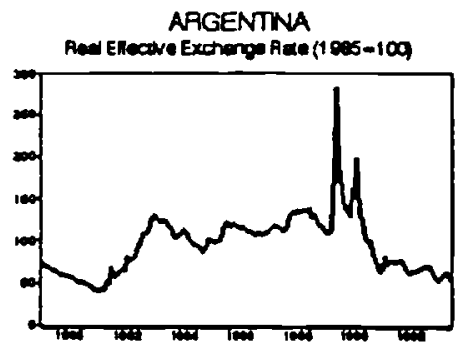

BRATh

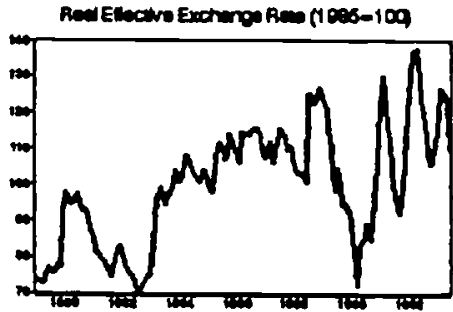

CHILE

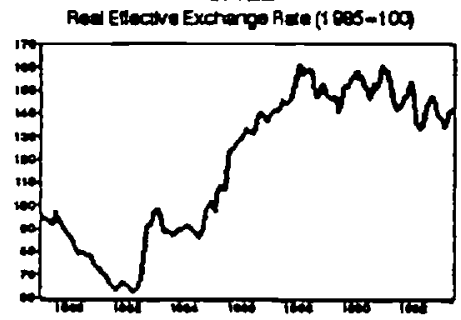

colomen

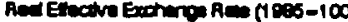

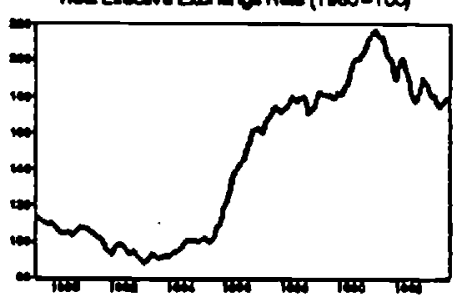

MEOCO

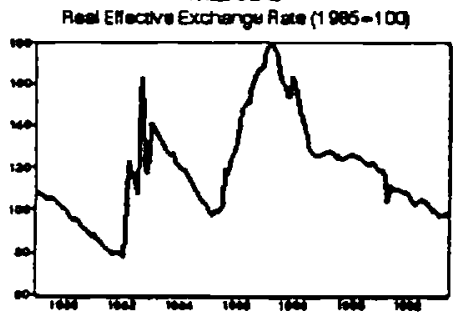

PERU

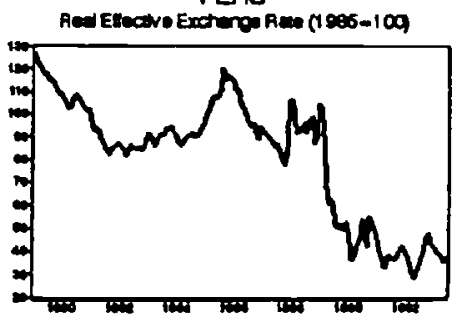

URUGUAY
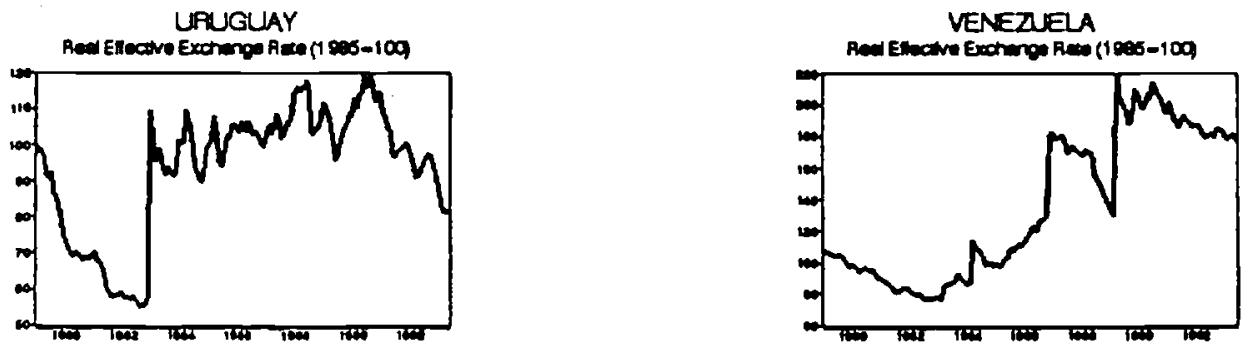

Note: An increase in the index denotes a real depreciation. 
Table 10 - CAPITAL INFLOWS AND NET RESOURCE TRANSFERS, LATIN AMERICA, 1981-92

$\begin{array}{lccc}\text { Years } & \begin{array}{c}\text { Net Capital } \\ \text { Inflows }\end{array} & \begin{array}{c}\text { Interest and } \\ \text { Profit Income }\end{array} & \begin{array}{c}\text { Net Resource } \\ \text { Transfers }\end{array} \\ 1982-85 & 55.3 & -111.7 & -56.4 \\ 1986-89 & 33.5 & -138.7 & -105.2 \\ 1990 & 17.0 & -35.7 & -18.7 \\ 1991 & 36.3 & -31.1 & 5.2 \\ 1992 \text { a/ } & 42.8 & -21.2 & 21.6 \\ \text { a/ Projection } & & & \\ \text { Source: Jaspersen (1992). }\end{array}$


Table 11 - NET CAPITAL INFLOWS AS A PERCENTAGE OF GDP IN SELECTED LATIN AMERICAN COUNTRUES

$\begin{array}{lcccccccccccc}\text { Country } & 1982 & 1983 & 1984 & 1985 & 1986 & 1987 & 1988 & 1989 & 1990 & 1991 & 1992 & \text { of } \\ \text { Argentina } & 2.5 & 0.4 & 2.3 & 2.8 & 1.6 & 2.2 & 2.8 & 0.3 & 0.5 & 3.0 & 5.7 \\ \text { Brazil } & 4.1 & 2.7 & 2.4 & 0.1 & 0.7 & 1.5 & -0.5 & 0.3 & 1.1 & 0.2 & \text { n.a. } \\ \text { Chile } & 4.2 & 2.6 & 10.5 & 8.6 & 4.3 & 5.4 & 5.0 & 5.5 & 11.7 & 3.0 & 7.8 \\ \text { Colombia } & 5.7 & 3.7 & 2.5 & 6.4 & 3.3 & 0.0 & 2.4 & 1.2 & 0.0 & -1.9 & \text { n.2. } \\ \text { Mexico } & 5.5 & -1.6 & -0.6 & -1.1 & 0.9 & -0.7 & -0.8 & 0.7 & 3.5 & 7.1 & \text { n.a. } \\ \text { Peru } & 7.8 & 3.8 & 5.3 & 2.4 & 3.6 & 3.7 & 5.4 & 2.9 & 3.6 & 2.2 & 3.4 \\ \text { Venezuela } & -1.9 & -4.7 & -3.4 & -1.7 & -1.8 & 1.1 & -1.7 & -7.9 & -7.4 & 3.7 & 5.8 \\ & & & & & & & & & & & & \end{array}$


triggering these capital movements are the recession in the industrialized world and the reduction in US interest rates. These authors suggest that once these world economic conditions change, the volume capital of capital flowing to Latin America will be reduced. This means that at that point the pressure over the real exchange rate will subside and a real exchange rate depreciation will be required.

The countries in the region have tried to cope with the real appreciation pressures in several ways. Colombia, for instance, tried to sterilize the accumulation of reserves by placing domestic bonds (OMAs) on the local market in 1991..$^{55}$ However, in order to place these bonds, the local interest rate had to increase making them relatively more attractive. This generated a widening interest rate differential in favor of Colombia, which attracted new capital flows that, in order to be sterilized, required new bond placements. This process generated a vicious cycle that contributed to a very large accumulation of domestic debt, without significantly affecting the real exchange rate. This experience shows vividly the difficulties faced by the authorities wishing to handle real exchange rate movements. In particular, this case indicates that real shocks-such as an increase in foreign capital inflows-cannot be tackled successfully using monetary policy instruments.

During 1993 Argentina tried to deal with the real appreciation by engineering a "pseudo" devaluation through a simultaneous increase in import tariffs and export subsidies. Although it is too early to know how this measure will affect the degree of competitiveness in the country, preliminary computations suggest that the magnitude of the adjustment obtained via tariffs-cum-subsidies package may be rather small. Mexico has followed a different route, and has decided to postpone the adoption of a completely fixed exchange rate. In October of 1992 the pace of the daily nominal exchange rate adjustment was doubled to 40 cents. As in the case of Argentina, it is too early to evaluate how effective these measures have been in dealing with the real appreciation trend. However, as pointed out earlier, a number of analysts of the Mexican scene have already argued that this measure is clearly not enough and that at some point in the near future other measures will have to be undertaken. At this point, however, it is difficult to know the exact way in which the implementation of the NAFTA will affect Mexico's equilibrium real exchange rate and its sustainable degree of competitiveness.

Chile has tackled the real appreciation by implementing a broad set of measures, including

${ }^{55} \mathrm{An}$ important peculiarity of the Colombian case is that the original inflow of foreign exchange came through the trade account. 
conducting exchange rate policy relative to a three-currency basket, imposing reserve requirements on capital inflows, allowing the nominal exchange rate to appreciate somewhat and undertaking significant sterilization operations. In spite of this multi-front approach, Chile has not avoided real exchange rate pressures. Between December of 1991 and December 1992 the Chilean bilateral real exchange rate appreciated by approximately $10 \%$. As a result of this, exporters and agriculture producers have been mounting increasing pressure on the government for special treatment, arguing that an implicit contract had been broken by allowing the real exchange rate to appreciate. This type of political reaction is, in fact, becoming more and more generalized throughout the region, and has been particularly important in Colombia, adding a difficult social dimension to the real exchange rate issue.

Although there is no easy way to handle the real appreciation pressures, historical experience shows that there are, at least, two possible avenues that the authorities can follow. First, in those countries where the dominant force behind real exchange rate movements is price inertia in the presence of nominal exchange rate anchor policies, the adoption of a pragmatic crawling peg system will usually help. This means that, to some extent, the inflationary targets will have to be less ambitious as a periodic exchange rate adjustment will result in some inflation. ${ }^{56}$ However, to the extent that this policy is supplemented by tight overall fiscal policy there is no room for concern regarding inflationary explosions.

Second, the discrimination between short term (speculative) capital and longer term capital goes a long way in helping resolve the preoccupations regarding the effects of capital movements on real exchange rates. To the extent that short term capital flows are more volatile, and thus capital inflows are genuinely long term, especially if they help finance investment projects in the tradables sector, the change in the RER will be a "true equilibrium" phenomenon, therefore it has to be recognized as such by implementing the required adjustment resource allocation. In practice, however, discriminating between "permanent" and "transitory" capital inflows is difficult; at the end policymakers are forced to make a judgment call.

\section{Regional Trading Blocks, Multilateralism and Industrial Countries Protectionism}

As we approach the 21st century, the world economy is moving towards the formation of a small number of trading blocks. Although the EEC and the North American Free Trade Agreement

\footnotetext{
${ }^{56}$ More specifically, with this option the one digit inflationary goal will be postponed.
} 
(NAFTA) are considered as the most formidable ones, a number of other trading blocks, with different degrees of cohesion, are rapidly emerging. Among these, ASEAN in Southeast Asia, with its dynamic and aggressive members, is especially promising. This is particularly so if the often-feared formation of a Yen Zone in the Pacific-including Japan and the ASEAN countries-takes shape in the next few years. ${ }^{57}$

In the last few years, however, some new important trading blocks in the Western Hemisphere have emerged, and are now attracting increasing attention from policy analysts. Among these, MERCOSUR and the Andean Pact, which jointly group nine Latin American countries, are two of the most important ones and have a volume of international trade that is expected to approach US $\$ 250$ billion per year by the year 2000. ${ }^{58}$ What makes this new integrationist effort in Latin America particularly interesting is that it is taking place within a context that strongly favors export promotion and the expansion of international trade throughout most of the developing world.

Interestingly enough, in addition to the somewhat large multi members trade agreements there has recently been a proliferation of bilateral integration agreements. Table 12 presents a brief summary of recently (post 1990) trade agreements negotiated trade agreements. The majority of the Latin countries have expressed keen interest in joining the NAFTA, and see the bilateral - or small multilateral, for that matter - agreements as an intermediate step. Table 13 contains data on the evolution of intraregional trade, and table 14 on bilateral trade for selected countries. Several important facts emerge from these tables. First, after having reached a low in 1985, intraregional trade has expanded greatly in the last few years. Interestingly enough, and contrary to popular belief, intaregional trade as a proportion of total trade is still significantly below its 1975-80 level.

Naturally, this means that there is significant room for further expanding intraregional trade. In this context it is interesting to notice that intraregional trade in East Asia borders $30 \%$ of total trade. In a recent study Losada (1993) has found that, with reduced trade impediments, distance is the main determinant of bilateral trade.

${ }^{57}$ See Schott (1991) for a general discussion on the recent formation, and prospects, of trading blocks in the World economy.

${ }^{58}$ MERCOSUR groups Argentina, Brazil, Uruguay and Paraguay. The members of the Andean Pact are Bolivia, Colombia, Ecuador, Peru and Venezuela. 
Table 12 - REGIONAL INTEGRATION AGREEMENTS IN THE AMERICAS AFTER 1990

\begin{tabular}{|c|c|c|c|c|}
\hline NUME NO MEMBERSHP & DATE & OQUECTIVE & CURAENT STATUS & MEMORMNOA (1900) \\
\hline $\begin{array}{l}\text { Andean Trade Priference Act } \\
\text { Boluble } \\
\text { Cotomble } \\
\text { Ecusedor } \\
\text { Pers } \\
\text { United slatos }\end{array}$ & 1091 & 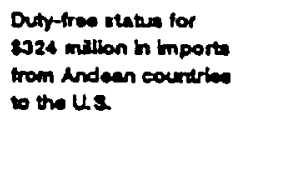 & Operational & \\
\hline Chie-Colombla FTA & 1093 & $\begin{array}{l}\text { Eotebliahment of } \\
\text { e tree trade eree }\end{array}$ & $\begin{array}{l}\text { Operational as of } \\
\text { damery } 1004 .\end{array}$ & \\
\hline Crib-Markeo FTA & 1001 & $\begin{array}{l}\text { Exabliahnent of a } \\
\text { trow trado erea } \\
\text { by Januer } 1008\end{array}$ & $\begin{array}{l}\text { Presert moximem } \\
\text { rectproeal tartit } 7.5 x\end{array}$ & 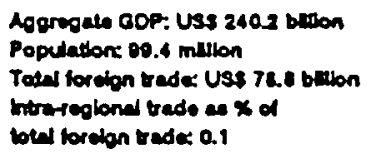 \\
\hline Chio-Vonazida FTA & 1903 & $\begin{array}{l}\text { Eethbibhment of } \\
\text { a tres trade wee } \\
\text { by } 1000\end{array}$ & 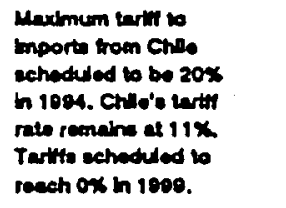 & 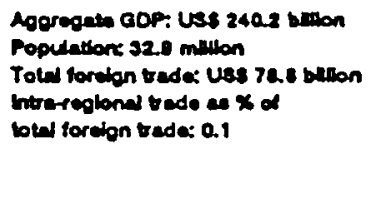 \\
\hline Calombla-Venaruela FTA & 1992 & $\begin{array}{l}\text { Extablahment of } \\
\text { a the trede erea } \\
\text { by } 1002\end{array}$ & 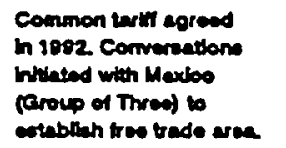 & 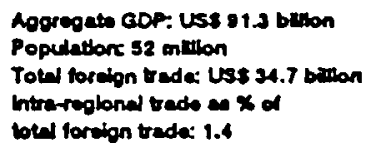 \\
\hline E Salvedor-Guatemale FTA & 1001 & $\begin{array}{l}\text { Entablaherient of } \\
\text { a tres trede erea }\end{array}$ & $\begin{array}{l}\text { Entered into } \\
\text { eperation ln Oetobe } 1801\end{array}$ & \\
\hline 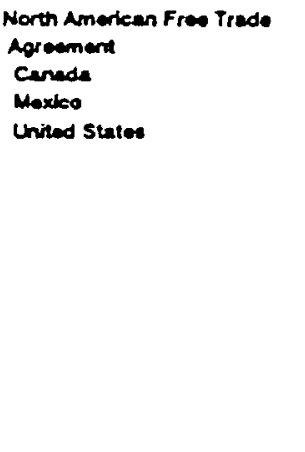 & 1902 & 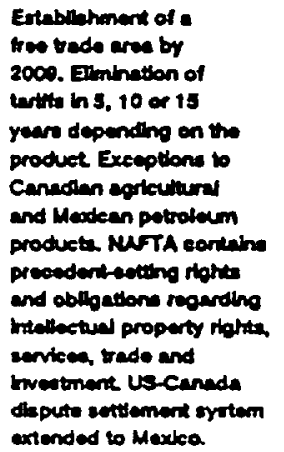 & 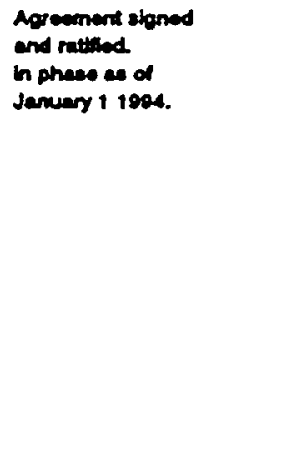 & 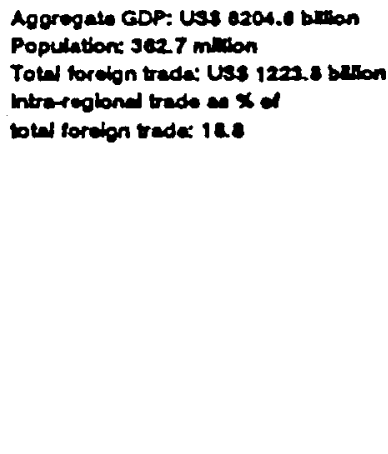 \\
\hline
\end{tabular}


REGIONAL INTEGRATION AGREEMENTS IN THE AMERICAS AFTER 1990 (Cont)

\begin{tabular}{|c|c|c|c|c|}
\hline NULE ANO MEMBERSHP & DATE & OUECTVE & CUARENT STATUS & MELOPWNOA (1000) \\
\hline 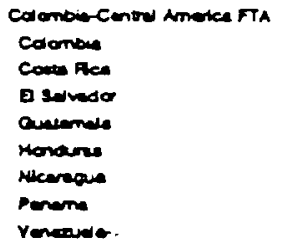 & 1000 & 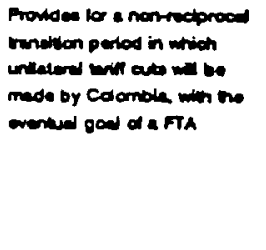 & 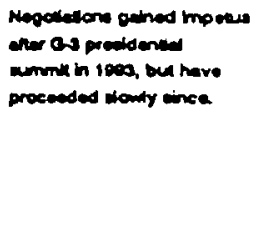 & \\
\hline $\begin{array}{l}\text { Gop of True Colambin } \\
\text { Uedeo-Vonende FTA }\end{array}$ & 1000 & 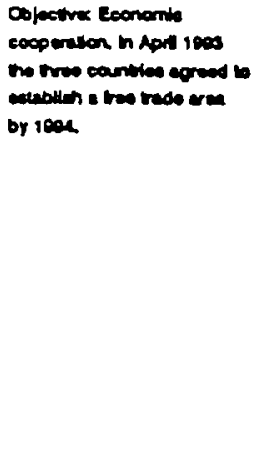 & 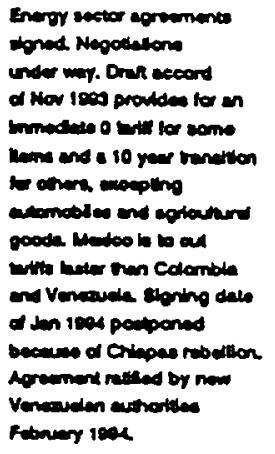 & 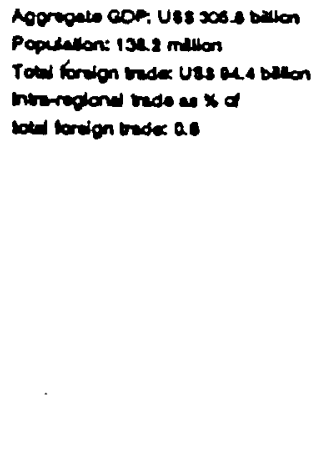 \\
\hline $\operatorname{coses}$ Pres-ladeo FTA & 1000 & 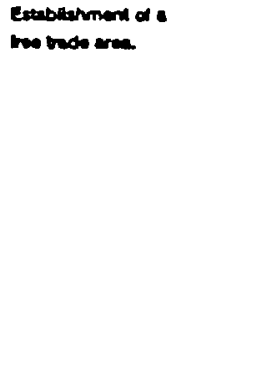 & \multicolumn{2}{|c|}{ 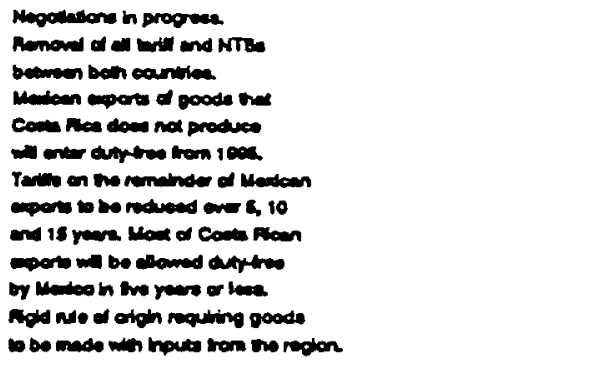 } \\
\hline 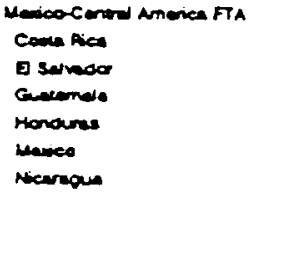 & 1002 & 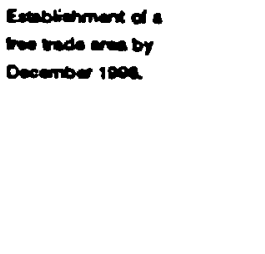 & 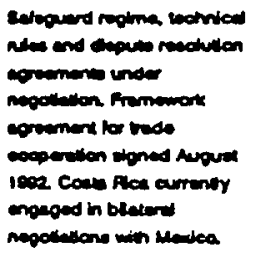 & 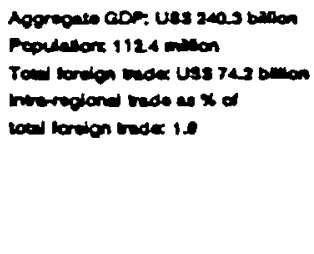 \\
\hline 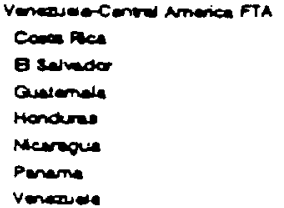 & 1502 & 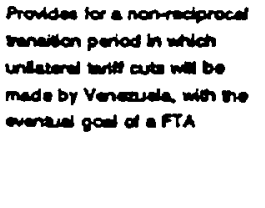 & 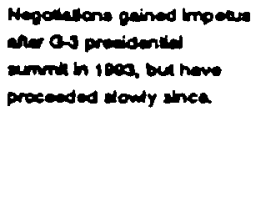 & \\
\hline
\end{tabular}


REGIONAL INTEGRATION AGREEMENTS IN THE AMERICAS AFTER 1990 (Cont)

\section{NUE MO MEMBERSH

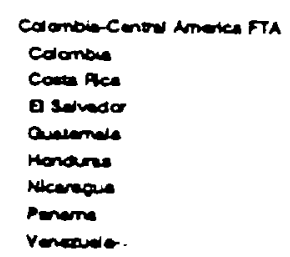

Gap of Trues Combir Hedco-Verade FTA

Coren Prea-leded FTA

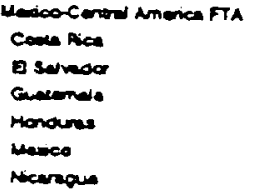

Vomouecentw America FTA Comen the G selvoder

Qnemere

Monderse

Nereones

Penems

Veneroude

Sare wabg (1000) nod Word Bank
1009

Provale lor a nonmectproced rmeven pertos in which

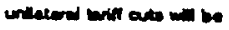
made by Calomble, win the cremenel goed of a PTA
Copecture teonomb cocp tration in Apil 1009

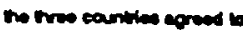
cublim a tres tredo eren by 1 cose

Extedienment of tre trede were

1002

$$
\text { Exabliatoment of }
$$
Decernoe tece.

1002

Providee lor a nonsedprecel
QUARENT STATUS

Mepoledord gemed mpous

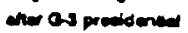
cumin in 1000, but have proceseded wowly ince.

MEMORWNOA (1000)

Enery sector soromente

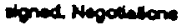
under wor. Oran eceord of Hor ises proulde to en inmedints o betil lor come now and 10 yeer renetion

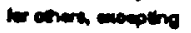

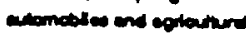
ocode thedo is bo ac

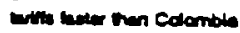
ond Vonsude Moning date - Ien ieas poutponed becane of Crepae rebellion. sorement resied by nom Veromalen monotiles Foboury ieas

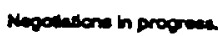
nonow ad all witi and NTE bermen beat courntere. undom mpores of poode the Com rice dow mat produce

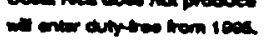
Tewe on mo moninder of Wedoen

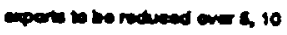

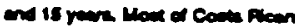

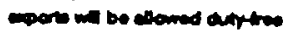
of lleded in two rewe or leve.

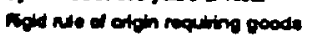
b bo made win houta trom tre neven

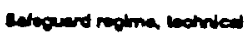

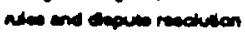
corvinanim under mopoluden Promowerk corvement for vele. copertion stoned Aupent sese coas Alice aurmenty ononoed in bleterd mopolations wien semice rencivon pertod in witheh

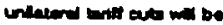

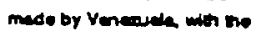
crentain god of a FTA

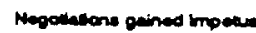
are Os primidentel numme in ices, but hewe procesded wouty unce.

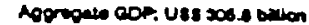
Population: $13 x 2$ mullion Tow fordon wade Uas Ma d bilon interapone bede es $x$ of led tordon tredes as
Aporopes con: Ued 200s binon Proplatarc 1124 minton

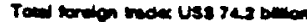
merepone that al $x$ of low tordon unde is 
ช

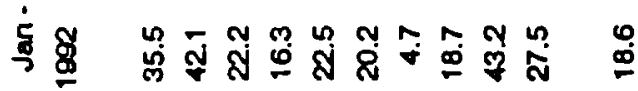

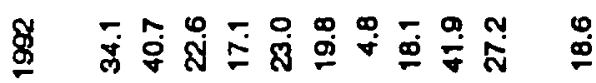

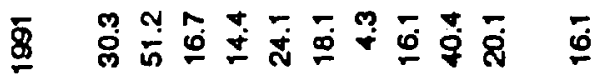

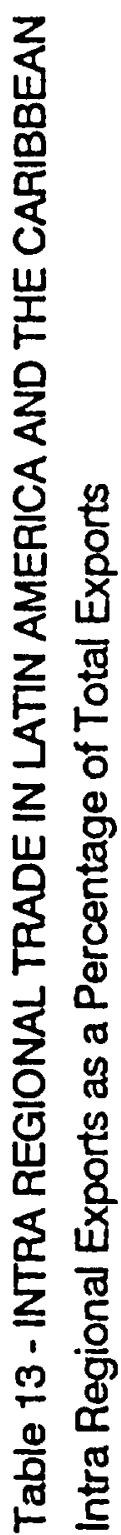

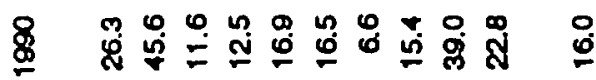

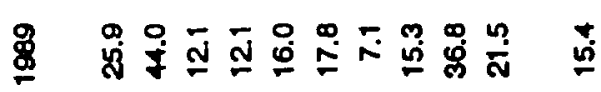

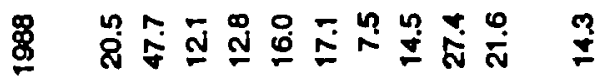

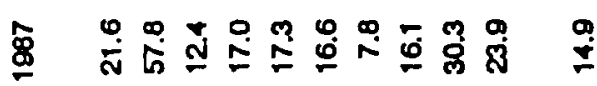

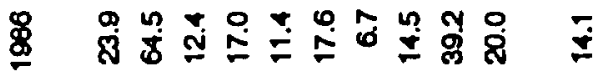

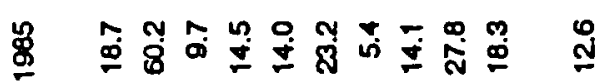

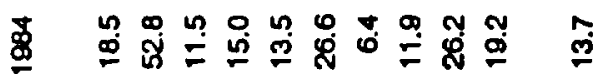

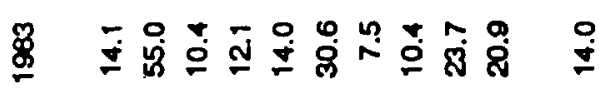

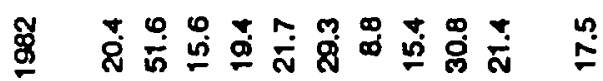

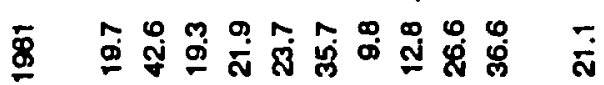

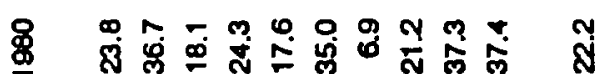

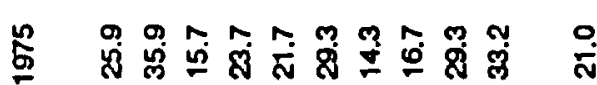

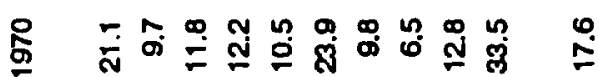

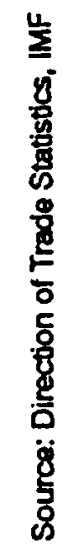


Table 14 - INTRA-REGIONAL EXPORTS

Fob values, percentage of total

\begin{tabular}{|c|c|c|c|c|c|c|c|c|c|c|c|c|c|c|c|}
\hline From & To & 1980 & 1981 & 1982 & 1083 & 1084 & 1985 & 1086 & 1087 & 1988 & 1080 & 1990 & 1001 & 1092 & 1093 \\
\hline ARO & BRA & 0.5 & 8.5 & 7.4 & 4.6 & 5.9 & 5.8 & 10.2 & 8.5 & 6.7 & 11.8 & 11.5 & 12.4 & 13.7 & 30.4 \\
\hline NAG & $\mathrm{CHL}$ & 2.7 & 2.1 & 2.2 & 2.4 & 1.0 & 1.3 & 2.0 & 2.3 & 2.0 & 3.7 & 3.7 & 4.1 & 4.7 & 6.7 \\
\hline ARO & $\mathrm{COL}$ & 0.5 & 0.6 & 0.0 & 0.8 & 0.7 & 1.0 & 0.9 & 1.0 & 0.9 & 0.8 & 0.6 & 0.7 & 0.8 & 1.0 \\
\hline ARO & PER & 1.5 & 1.0 & 1.4 & 1.2 & 1.0 & 1.9 & 2.0 & 2.2 & 1.9 & 1.7 & 15 & 1.7 & 1.8 & 2.2 \\
\hline ARO & VEN & 0.8 & 1.1 & 1.3 & 0.7 & 1.4 & 0.9 & 0.7 & 0.0 & 1.4 & 1.0 & 1.2 & 1.7 & 1.7 & 1.8 \\
\hline BRA & ARO & 5.4 & 3.8 & 3.2 & 3.0 & 3.2 & 2.1 & 3.0 & 3.2 & 2.0 & 2.2 & 2.1 & 4.7 & 8.5 & 0.2 \\
\hline BRA & CHL & 2.2 & 2.7 & 1.4 & 1.0 & 1.0 & 0.8 & 1.1 & 1.4 & 1.0 & 2.1 & 15 & 2.1 & 2.6 & 20 \\
\hline BRA & COL & 0.7 & 0.9 & 1.3 & 0.7 & 0.6 & 0.4 & 0.5 & 0.5 & 0.7 & 0.0 & 0.5 & 0.5 & 1.0 & 1.0 \\
\hline BRA & PER & 0.6 & 1.2 & 1.1 & 0.3 & O.s & 0.4 & 0.7 & 0.0 & 0.6 & 0.4 & 0.5 & 0.7 & 0.6 & 0.6 \\
\hline BAM & VEN & 1.1 & 1.8 & 2.3 & 12 & 1.4 & 12 & 1.6 & 1.4 & 15 & 0.0 & 0.0 & 1.4 & 1.2 & 1.2 \\
\hline $\mathrm{CHL}$ & ARO & 6.0 & 4.8 & 4.1 & 3.1 & 3.2 & 2.2 & 3.8 & 3.4 & 2.3 & 1.3 & 1.3 & 2.9 & 4.6 & 5.1 \\
\hline $\mathrm{CHL}$ & BRA & 9.8 & 7.3 & 8.3 & 4.3 & 62 & 5.4 & 6.0 & 6.8 & 4.7 & 0.4 & 5.7 & 8.0 & 4.5 & 8.2 \\
\hline CHL & $\mathrm{COL}$ & 1.0 & 1.0 & 12 & 1.1 & 12 & 1.4 & 1.0 & 1.0 & 0.8 & 1.0 & 0.9 & 0.6 & 0.7 & 0.9 \\
\hline CSA & PER & 1.5 & 1.8 & 1.3 & 1.0 & 1.2 & 1.2 & 1.0 & 1.7 & 0.0 & 0.7 & 0.8 & 1.6 & 1.7 & 15 \\
\hline $\mathrm{CHL}$ & VEN & 1.7 & 1.6 & 1.2 & 0.8 & 1.1 & 0.0 & 1.0 & 1.4 & 1.5 & 0.4 & 0.4 & 0.6 & 0.7 & 0.8 \\
\hline $\mathrm{COL}$ & ARO & 1.7 & 1.7 & 1.2 & 1.4 & 1.7 & 1.0 & 1.3 & 0.8 & 1.0 & 0.6 & 0.4 & 0.5 & 1.0 & 1.3 \\
\hline $\mathrm{COL}$ & BRA & 0.2 & 0.2 & 0.1 & 0.2 & 0.4 & 0.2 & 0.2 & 0.4 & 0.2 & 0.4 & 0.4 & 0.7 & 0.0 & 2.0 \\
\hline $\mathrm{COL}$ & CHL & 1.8 & 1.0 & 0.4 & 0.4 & 0.5 & 0.6 & 0.6 & 2.0 & 2.4 & 2.3 & 2.4 & 2.2 & 1.3 & 1.3 \\
\hline $\mathrm{CO}$ & PER & 0.7 & 1.5 & 9.1 & 0.6 & 0.7 & 0.0 & 1.4 & 2.4 & 1.7 & 1.1 & 1.3 & 2.0 & 4.2 & 4.6 \\
\hline $\mathrm{COL}$ & VEN & 7.1 & 11.5 & 11.8 & 3.8 & 2.6 & 3.6 & 2.9 & 4.4 & 4.4 & 3.2 & 3.0 & 6.9 & 8.8 & 73 \\
\hline PER & ARO & 1.5 & 0.8 & 0.8 & 1.2 & 1.1 & 1.2 & 23 & 1.5 & 0.0 & 0.5 & 0.8 & 0.9 & 0.8 & 1.0 \\
\hline PER & BRA & 3.2 & 1.5 & 2.2 & 2.0 & 1.5 & 1.8 & 20 & 4.2 & 3.0 & 4.5 & 3.9 & 3.1 & 4.7 & 0.0 \\
\hline PEA & CHL & 1.2 & 1.0 & 1.2 & 1.5 & 1.6 & 1.7 & 2.0 & 1.2 & 1.5 & 1.0 & 1.7 & 13 & 12 & 1.2 \\
\hline PER & $\mathrm{col}$ & 1.4 & 2.8 & 4.2 & 1.7 & 2.4 & 2.5 & 2.0 & 2.4 & 3.1 & 3.0 & 2.8 & 3.2 & 2.5 & 3.2 \\
\hline PER & VEN & 1.3 & 1.4 & 1.7 & 1.0 & 1.6 & 1.4 & 1.8 & 2.4 & 3.1 & 12 & 1.7 & 2.4 & 3.1 & 3.6 \\
\hline VEN & ARO & 0.3 & 0.2 & 0.1 & 0.0 & 0.0 & 0.0 & 0.1 & 0.0 & 0.2 & 0.2 & 0.0 & 0.1 & 0.2 & 0.2 \\
\hline VEN & BFU & 3.5 & 4.7 & 5.3 & 3.7 & 3.2 & 1.8 & 0.8 & 1.4 & 1.5 & 2.0 & 1.8 & 1.8 & 2.8 & 2.9 \\
\hline VEN & $\mathrm{CHL}$ & 1.3 & 1.7 & 1.4 & 1.4 & 1.4 & 1.7 & 1.4 & 1.3 & 1.4 & 1.2 & 1.0 & 0.0 & 0.8 & 0.3 \\
\hline VEN & $\mathrm{col}$ & 1.4 & 1.0 & 1.0 & 22 & 2.0 & 1.6 & 1.2 & 0.1 & 1.7 & 2.1 & 2.1 & 1.5 & 2.2 & 2.5 \\
\hline VEN & PEA & 0.1 & 0.1 & 0.1 & 0.1 & 0.1 & 0.2 & 0.4 & 0.1 & 0.5 & 0.2 & 0.2 & 0.5 & 0.8 & 0.0 \\
\hline
\end{tabular}

(") Dala through October 1993 except for the case of exporte from Ngentina to Braxll, that corresponde to May 1993.

Source: Oirection of Trade Statstica, IMF 


\section{1 MERCOSUR}

The Mercado Común del Sur (MERCOSUR) is a trade agreement signed by Argentina, Brazil, Paraguay and Uruguay in $1991 .{ }^{59}$ Its main goal is to eliminate all tariffs for intra-regional trade by December of 1994, and to establish a common external tariff that would guide international trade between the member countries and the rest of the world. What is particularly interesting about MERCOSUR is that it groups the two largest countries in South America - Argentina and Brazil with two of the smallest. ${ }^{60}$ Table 15 contains data on some basic indicators on these countries, as well as of Andean Pact members (see below). These data clearly highlight some of the differences across them-including size, recent performance and extent of international indebtedness. There is little doubt that the future of MERCOSUR will depend on the policies of the two largest countries Argentina and Brazil; Uruguay and Paraguay, as (much) smaller members, will play a very limited role in the political-diplomatic process that will determine the actual characteristics of the agreement.

Table 15, however, does not capture some important recent economic developments that are likely to impact on the future of this agreement. While Argentina has recently been able to make substantial progress in attaining macroeconomic stability and in launching an ambitious privatization program, Brazil has faced economic and political problems. The resignation of President Collor added further uncertainty to the future of Brazil's reform programs. Brazil's inability to control inflation is particularly serious. In fact there is widespread agreement that many of the troubles encountered by early integrationist attempts in Latin America during the 1960s and 1970s, had their roots in the marked differences in macroeconomic performance, including inflation and exchange rate policies. ${ }^{61}$

The differences in strategy regarding the speed and depth of privatization and trade reform suggest that disagreements could easily erupt between Argentina and Brazil with regard to points closely related to MERCOSUR. In particular, an increasingly large number of observers in Argentina

${ }^{59}$ The legal document that sets the basis for MERCOSUR is the Asuncion Treaty. This treaty had its origins in an integration act signed between Argentina and Brazil in 1986. New acts were signed between these two countries in 1989 and 1990 . For details see Nogues and Quintanilla (1992).

${ }^{60} \mathrm{Chile}$ was invited to join, but declined. Chile, however, is moving briskly towards integration with Argentina through the signature of bilateral agreements.

${ }^{61}$ Baldinelli (1991) discusses some of the most important macroeconomic policies in the MERCOSUR countries. 


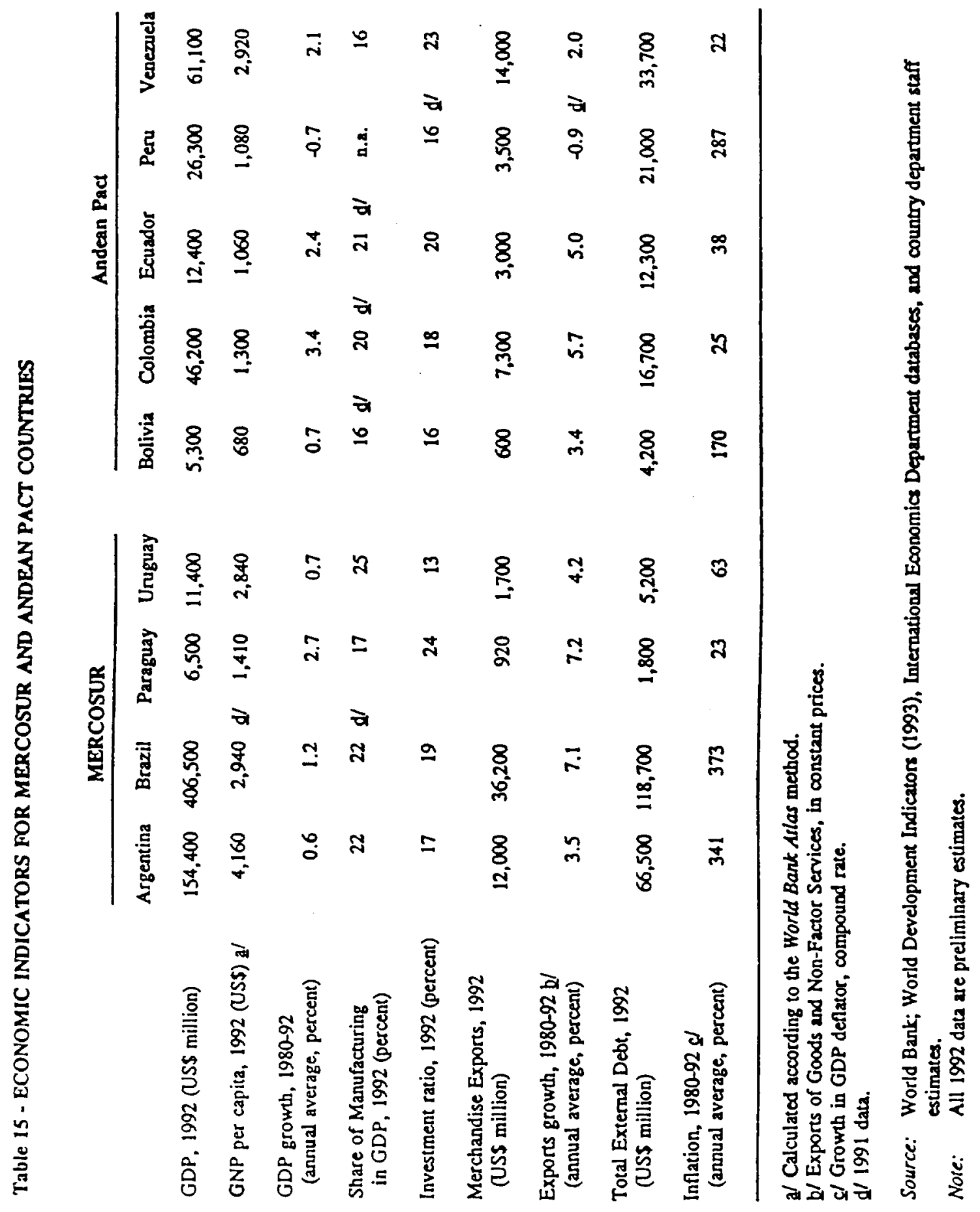


are concerned that Brazil will insist on a higher common external tariff than what would be acceptable to Argentina. The current structure of protection in the individual members of MERCOSUR, discussed above, shows that there may indeed be some room for disagreement. While Argentina has recently embraced a significant free trade stance-slashing tariffs, reducing non-tariff barriers (NTBs) considerably and completely eliminating export taxes-Brazil is aiming at a higher and more variable tariff structure.

Table 16 contains data on the recent level of intra-regional trade for the MERCOSUR members. As can be seen, intra-regional trade is more important for Argentina (with 17\%) than for Brazil $(11 \%){ }^{62}$ This suggests that it is in fact Argentina who is bound to lose more in the eventuality that MERCOSUR is aborted. From a political economy perspective this means that it is likely that in negotiations regarding policies toward third parties, Brazil may have an important edge. If this is the case, and MERCOSUR is implemented around high import tariffs-with a range of 0 $40 \%$, which corresponds to the Brazilian liberalization target-it is very unlikely that its members would experience a net gain over the long run. More specifically, in the case of Argentina joining a trade agreement with Brazilian-level common external tariff it is likely to result in "trade diversion" that would more than offset any benefits derived from trade creation. ${ }^{63}$

Table 17 presents the expected path of elimination of tariffs for intra-regional trade within MERCOSUR. Two main differences with respect to previous attempts at integration immediately stand out. ${ }^{64}$ First, there is a very high degree of automaticity in the integration process within MERCOSUR, and second, the total time frame allowed for integration is significantly shorter than those attempted previously (Edwards and Savastano, 1989). These features of the Asuncion Treaty

${ }^{62}$ The data in the table refer to 1992 . Historically, Brazil's intra-regional trade has been significantly lower-on the order of $4 \%$ of total exports.

${ }^{63}$ The higher the common external tariff, the more likely it is that a Customs Union will have net negative welfare effects on its members. The reason is that in this case there will be additional trade diversion. Commodities that, at the original tariff, were imported from the least expensive source will be imported from a less efficient regional member. On trade creation and trade diversion see, for example, Dornbusch (1989). Notice, however, that GATT does not allow for a common tariff exceeding the members average before the union. It is unclear, however, whether this provision can actually be enforced. (1989).

${ }^{64}$ On historical integrationist attempts in Latin America see Edwards and Savastano 
Table 16 - TRADE AMONG MERCOSUR COUNTRIES, 1992

$\begin{array}{lcc}\text { Argentina } & \begin{array}{c}\text { Percentage } \\ \text { of Exports }\end{array} & \begin{array}{c}\text { Value } \\ \text { (USS Millions) }\end{array} \\ \text { Brazil } & 17 & 2,100 \\ \text { Paraguay } & 37 & 4,100 \\ \text { Uruguay } & 34 & 220\end{array}$

Source: Direction of Trade Statistics, LMF 
Table 17 - PERCENTAGE OF IMPORTS SUBJECT TO FREE TRADE IN MERCOSUR

$\begin{array}{lc}\text { Date } & \text { Percentage } \\ 6 / 91 & 47 \\ 12 / 91 & 54 \\ 6 / 92 & 61 \\ 12 / 92 & 68 \\ 6 / 93 & 75 \\ 12 / 93 & 82 \\ 6 / 94 & 89 \\ 12 / 94 & 100\end{array}$

Source: Treaty of Asuncion (1991) 
are a clear reflection that, even in an agreement dominated by a not fully enthusiastic reformer such as Brazil, the rules governing opening up are quite aggressive and dynamic. An important, and as yet unresolved question, however, is whether this ambitious automatic intra-regional liberalization program can be sustained in the presence of major macroeconomic imbalances in Brazil.

\section{VI.2 The Revival of the Andean Pact}

In November of 1990, more than two decades after its initial launching, the Andean Pact was renewed by the Presidents of Bolivia, Colombia, Ecuador, Peru and Venezuela. ${ }^{65}$ The new agreement, which came to be known as the Acta de la Paz, established a number of ambitious targets, including: ${ }^{66}$ (1) the implementation of a free trade zone in the region by 1992; (2) an agreement on the level and structure of the Common External Tariff (CET) by December 1991; (3) the implementation of the CET by December 1995; (4) the liberalization of maritime and air transportation; and (5) the facilitation of foreign investment and capital mobility within the Andean group.

It is important to notice that there is great heterogeneity among the countries in the pact (see table 15). These differences refer both to the economic structure, as well as to macroeconomic policy. For instance, while Bolivia and Venezuela are moving steadily towards low inflation and price stability, Peru continues to struggle in the area of macroeconomic management and Venezuela is in a sort of macroeconomic limbo due to the recent political upheaval. Despite large increases during 1992 and 1993, the volume of intra-regional trade remains somewhat limited (see table 18). This reflects both the fact that factor endowments are rather similar across these countries, and that there have been significant impediments to intra-regional trade. These have been related both to administrative and commercial regulations, as well as to an extremely poor land transportation system within the countries in the region. The low level of current intraregional trade suggests, in fact, that there is a possibility of significant trade diversion once the Customs Union is launched. Whether this actually happens will depend largely on the level and structure of the Common External Tariff. This, in fact, has become a highly controversial issue that is currently threatening the furure of the Pact.

As the discussion on the extent of the reforms in Section V.2 showed, the Andean Pact nations have a significantly more homogeneous structure of protection than the MERCOSUR countries (see

\footnotetext{
${ }^{65}$ Chile, an original signatory of the Pact declined to participate.

${ }^{66}$ Nogues and Quintanilla (1992) provide a detailed account of the Acta de la Paz.
} 
Table 18 - TRADE AMONG ANDEAN PACT COUNTRIES, 1992

$$
\begin{aligned}
& \text { Percentage } \\
& \text { of Exports }
\end{aligned}
$$

Bolivia

Colombia

Ecuador

Peru

Venezuela
13

13

3

8

3
Value

(US\$ Millions)

90

920

90

270

510

Source: Direction of Trade Statistics, IMF 
Table 2). However, in spite of this, there are still some important differences regarding the objectives of overall trade policy. While Bolivia and Peru have been pursuing aggressive free trade reforms, Colombia and Venezuela have maintained a more protectionist stance, arguing that higher tariffs are still necessary to encourage the formation of a strong industrial base. More recently, however, the Colombian government has been more inclined to accelerate its opening up and its integration to the rest of the world. The differences regarding commercial policies have already generated some serious friction within the Acta de la Paz signatories, with Peru's threatening to abandon the Pact altogether if the common external tax is set at a rate that is considered by its authorities as "excessively" protectionist. 67

In December of 1991, and in accordance with the Acta de La Paz, a new agreement was signed by the Andean Group's political authorities. The Act of Barahona established free trade zones between Bolivia, Colombia and Venezuela, starting on January 1, 1992. Ecuador and Peru were expected to join the free trade zone later in July of 1992 . With respect to the common external tariff the Act of Barahona established an extremely cumbersome mechanism, with exceptions across both countries and goods. More specifically, according to this act the CET should have four levels $(0,5$, 10,15 percent), except for Bolivia who would only have levels of 5 and 10 percent. There were also exceptions for agricultural goods, automobiles and non-competing regional products, where the tariff levels are still to be determined. From the beginning this agreement on CET had a serious problem, including the fact that Rules of Origin were not determined. This means that for practical purposes it is possible that the lowest tariffs (those of Bolivia) will become the effective CET for the region as a whole.

In May of 1992, only a few months after the CET agreement, the future of the Andean Pact suffered a blow, when Peru unilaterally decided to suspend the preferential treatment granted to imports from within the Pact. This action was part of a general Peruvian policy aimed at forcing a lower CET on the Pact. As a consequence of this the governments of Colombia and Venezuela decided to suspend negotiations with Peru on the Common External Tariff. It is too early to say whether the Andean integrationist movement will continue to move forward, or whether it will result in its (second) death. While negotiations at the diplomatic level are still on their way the individual Pact members have proceeded with their policies.

${ }^{67}$ The new political development in Peru, and especially the Fujimori "Coup", have added considerable uncertainty to the integrationist process. 


\section{3 The Revitalization of the Central American Common Market}

During the early and mid-1980s, and largely as a result of the international debt crisis, the Central American Common Market began to break down. Most countries in the area responded to the debt crisis by imposing massive nontariff barriers, including multiple exchange rates. The most important consequence of this increase in protectionism was that soon the CACM common external tariff ceased to be relevant as, de facto, the different members had different implicit tariffs for imports coming from outside the region. In 1986 the CACM received a fatal blow when the Central American payments clearing mechanism collapsed. ${ }^{68}$

In July of 1991, and after several years of independently undertaking trade adjustment, the Presidents of the Central American nations decided to revitalize the Central American Common Market. ${ }^{69}$ Three important features of the renewed CACM are worth noting: first, the agreedupon common external tariff contemplates a range between 5 and 20 percent. This is significantly lower than the tariff structure most Central American countries have had until recently and represents a clear move towards trade liberalization (see Table 19). Second, the newly revitalized CACM includes two new countries: Panama, which never joined the original agreement, and Honduras which had withdrawn in 1969. And, third, in recent years the members of the CACM have very actively utilized export promotion schemes as ways to diversify and increase exports. ${ }^{70}$ Although it is still too early to know how successful these schemes have been, recent evidence presented by Saborio and Michalopoulos (1992) suggest that these have been very costly from a fiscal perspective, without having accomplished significant effects on export expansion over and above what has been obtained through more competitive real exchange rates.

The renewed CACM is a far cry from the agreement originally enacted in the 1960 s. Nowadays, instead of promoting an inefficient and forced industrialization process behind protective walls, the countries in the region are uniting forces as a way to compete internationally and rapidly expand exports.

${ }^{68}$ This collapse was partially the result of Nicaragua's accumulation of very large debt. See Saborio and Michalopoulos (1992).

${ }^{69}$ The details of the agreement appear in the Declaration of San Salvador, July 17, 1991.

${ }^{70}$ See, for example, Saborio and Michalopoulos (1992). 


\title{
Table 19 - TARIFF STRUCTURES IN THE CENTRAL AMERICAN COMMON MARKET \\ (percentages)
}

\author{
Prereform Average legal \\ average tariffs a tariff $1987 \quad 1991$ range 1993 range 1995 range
}

$\begin{array}{llllll}\text { Costa Rica } & 52 & 26 & 10-50 & 5-30 & 5-20 \\ \text { El Salvador } & 48 & 23 & 5-35 & 5-25 & 5-20 \\ \text { Guatemala } & 50 & 25 & 5-37 & 5-20 & 5-20 \\ \text { Honduras } & 41 & 20 & 4-35 & 5-20 & 5-20 \\ \text { Nicaragua } & 54 & 21 & 5-20 & 5-20 & 5-20\end{array}$

a Ad valorem equivalent of average external tariff.

Source: Saborio and Michalopoulos (1992). 


\section{VI.4 The North American Free Trade Agreement}

As in most of Latin America, Mexico's trade policy was characterized for decades by a significant degree of protectionism and inward orientation. As discussed above, starting in late 1985 and as a component of a major structural adjustment plan, Mexico embarked on an ambitious unilateral trade liberalization program. Import tariffs were halved and import licenses were reduced from $92 \%$ to $20 \%$.

After almost a decade of intensive, and often confrontational, trade negotiations, the U.S. and Mexico agreed in November of 1990 to move towards a free trade agreement. In February of 1991 , Canada, Mexico and the U.S. decided to start negotiating a North American Free Trade Agreement (NAFTA), and later that year the U.S. Congress approved the "fast track" treatment to the agreement. On August 12, 1992 the three parties announced that an agreement had been reached on the exact nature of the proposed agreement.

Both the U.S. and Mexican negotiators had originally expected that the U.S. government would have submitted the agreement to Congress in the summer of 1992 . However, U.S. presidential politics, plus some deep disagreements regarding some details of the agreement delayed its submission to the U.S. Congress until late 1993. The most important areas of contention between U.S. and Mexican negotiators referred to: (1) defining rules of origin for specific products, including automobiles; (2) establishing the rules for agricultural trade; (3) determining the treatment that will be given to automobiles; (4) workers' protection in Mexico; and (5) environmental rules in Mexico, especially on the border. Of these, perhaps the most important problem is defining rules of origin. After a grueling debate, and the hasty implementation of a number of "side agreements", the NAFTA was finally passed by the U.S. Congress in November of 1993 . The agreement establishes very different speeds of liberalization for different sectors. For example, according to the final text, in order for motor vehicles to be subject to free trade within NAFTA, their regional value added should initially be at least $50 \%$. This figure, however, will increase slowly for a period of eight years until it reaches $62.5 \%$. Regarding the agriculture sector, the agreement proposes, for most items, a very slow tariff elimination over a period of 15 years.

A number of authors have argued that the NAFTA will have a severely negative effect on Mexico's agricultural sector (ITAM, 1994). In fact, the January 1993 uprising in Chiapas by the Zapatistas Mayan indians was, at least in part, the result of the perception that the NAFTA would "wipe out" traditional agriculture in that state. A recent study by Velez and Rubio (1994) indicates that production of most grains in Mexico - sorghum, wheat, barley, soy beans, beans, and maize - 
will suffer considerably by the implementation of the free trade agreement. Grain production in Mexico is highly inefficient, and subject to a significant degree of protection. In order to avoid a devastating impact of free trade on Mexican agricultura, the NAFTA considered the implementation of high initial tariffs - at a height that would replicate the protection granted by traditional licenses. These tariffs will be phased out gradually through time. For instance, the agreement established an initial import tariff on barley of $128 \%$, which will be subject to gradual elimination in ten years. Maize is, perhaps, the most dramatic case of inneficient production. Mexico's average yields are approximately 1.7 tons per hectare, barely one fourth of average yields in the U.S. The NAFTA established a tariff-quota for maize imports into Mexico. Initially it will be possible to import 2.5 millions tons free of duties. During the first year of NAFTA, imports above that level will be subject to a $215 \%$ tariff, which will be subject to complete liberalization in 15 years.

As Nogues and Quintanilla (1992) have argued, the heavy media coverage received by NAFTA negotiations has tended to overshadow the broader commitment made by the Mexican government towards freer trade. In fact, after becoming a member of GATT in 1986, Mexico bas consistent and systematically pursued freer trade policies. This has been reflected in the reduction in trade impediments, in the signing of bilateral trade agreements with Chile (1991), and in the current discussions to sign free trade agreements with Venezuela (1993), Colombia and Central America. The recent negotiations to become a member of the OECD also underlie the Mexican government vision of the importance of freer trade as a fundamental component for the national development strategy for the next decades. However, in order for this policy position to be translated into additional gains in productivity and welfare, it will be necessary to further reduce tariffs and license coverage, and, as discussed in the preceding sections, to effectively broaden the reforms to all areas of the economy, and especially agriculture. Although Mexico has come a long way, there is still a long road towards achieving a protective structure similar to that of its most important trade partners, including the U.S. and Canada.

\section{V.5. GATT and the Prospects for Global Trade Liberalization}

There is little doubt that Latin America has embarked on one of the most substantial unilateral trade liberalization reforms in modern economic history. However, a serious concern among the region's political leaders has been the lack of reciprocity on behalf of the industrial countries. While the Latin American nations have greatly opened up their trade sector to foreign competition, most industrial nations have continued to follow protectionist practices. In fact, as captured in Table 20 , 


\section{Table 20 - PROTECTION AGAINST LATIN AMERICAN EXPORTS BY OECD COUNTRIES}

Non-Tariff Barrier Coverage Ratios, mid-1980s (percent)

COUNTRY

Argentina

Brazil

Chile

Mexico

Peru

Uruguay

Venezuela

Central America

Average LAC

Source: Leamer (1990)
IMPORT-WEIGHTED

LEVEL OF THE NTB

63.0

38.3

23.8

8.4

12.8

23.2

3.2

17.1

28.6 
the industrial countries have traditionally imposed significant restrictions on Latin American exports. These trade impediments have taken mostly the form of non tariff barriers (NTBs), including quotas, prohibitions and licenses. The approval of GATT's Uruguay Round package in December 1993 provides some hope that in the years to come multilateralism could result in a more open world trade system - see Table 21 for a summary of the Uruguay Round most important implications for Latin America.

Before 1947, when the first round of multilateral trade negotiations was held in Geneva, average tariff protection in industrial countries was above $100 \% .^{71}$ Fueled by the Smoot-Hawley Tariff Act of 1930, protectionist ideas grew during the first decades of the century leading the world economy to the Great Depression. After seven rounds of GATT-sponsored negotiations, that average had been reduced to $5 \%$ by 1993 . However, in spite of this lowering in import tariffs, most industrial countries continued to use extensively an array of NTBs that effectively raised the degree of protectionism. In fact, by 1993 LDCs imports into some industrial countries were, for all practical purposes, prohibited.

The liberalization of world trade contemplated in the Uruguay Round will be implemented gradually throughout a ten years period. From an institutional point of view one of the most important elements of the agreement is the creation of the, World Trade Organization which is suppose to replace the GATT in 1995 . Market access negotiations, which will largely determine the actual extent of the liberalization effort, are expected to be completed in the Morocco ministerial meeting of April 1994.

Some authors (Corden 1984, for example), have argued that regional integration schemes will act as intermediate steps towards a more perfect multilateral system based on GATT/WTO. There are, however, some problems with this idea. The current structure of trading blocs is not cooperative across groups, so that the gains from more intra-bloc trade have to be compared with the losses from less trade between groups. Moreover, the U.S. is currently pushing forward a policy of reciprocity rather than free trade.

The Uruguay Round covers trade in agriculture and textiles, services and investment regulations. Overall, according to the agreement industrial countries' average trade-weighted tariffs on LDC's exports will have to be reduced in $34 \%$ in ten years (from 6.4 to $4 \%$ ). Developing countries, in turn, have committed themselves to increase the coverage of duties bound and to remove

71 This, and the paragraphs that follow are based on Losada (1994). 


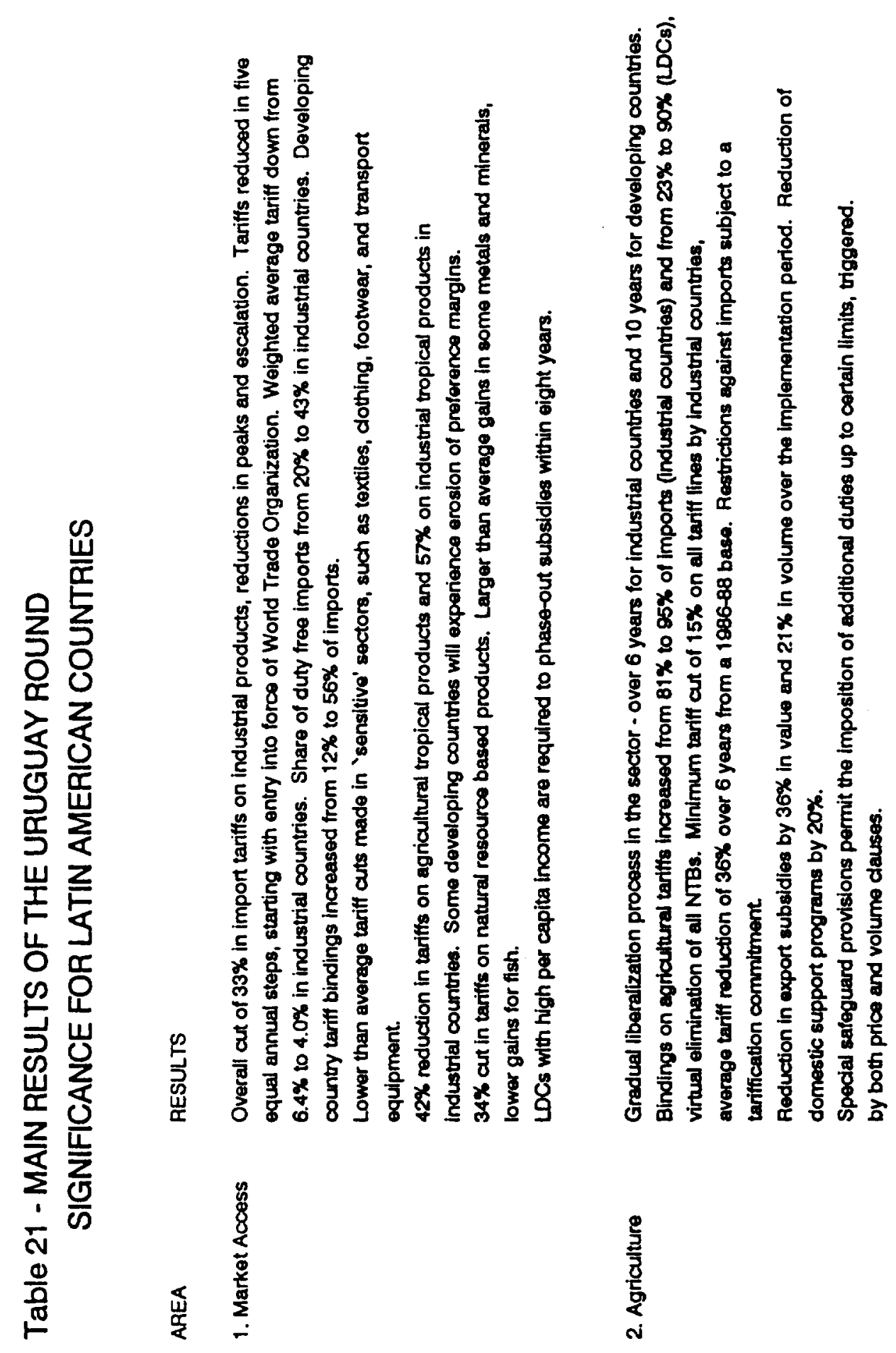




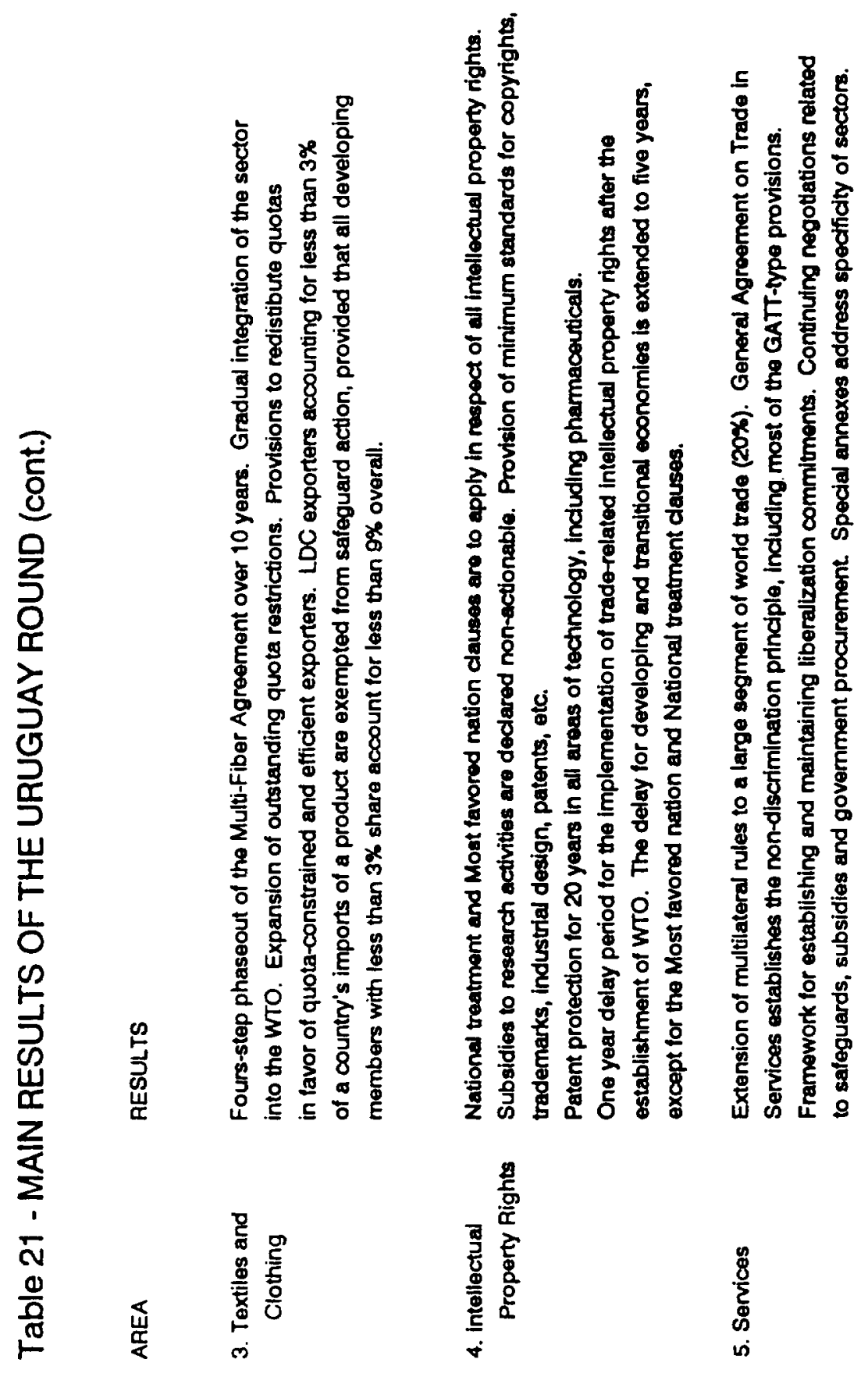


export subsidies. In some cases the reduction is expected to be impressive; Brazil for instance committed herself to lowering import tariffs from a maximum of 105 percent to a ceiling of 35 percent. Trade distorting investment measures, such as local content requirements, are also to be eliminated in 5 to 7 years.

The streamlining of intellectual property protection is expected to help some developing countries that have started exporting knowledge-intensive goods, such as software and agriculturerelated technology.

However, the liberalization measures agreed upon in December 1993 are rather timid in some areas especially in agriculture --, and the implementation timetable is too lengthy. Safeguard rules are expected to be softened, and could be introduced in the future in a discriminatory way and without compensation. Unfortunately, it is possible that these antidumping measures will give rise to a new form of disguised protectionism.

The successful completion of the Round is expected to provide both static and dynamic gains to the world economy. The developing countries' share of these gains will be about one third. Trade is expected to grow by $12 \%$ in the next 10 years, due exclusively to the Round. LDCs will not receive a significant share of the dynamic gains, since economies of scale and technological spillovers through greater innovation are likely to accrue to exporters of industrial goods. 


\section{References}

Agacino, R., G. Rivas, and E. Román. 1992. “Apertura y eficiencia productiva: La experiencia Chilena, 1975-1989." Working Paper 113. Inter-American Development Bank, Washington, D.C.

Balassa, Bela. 1971. The Structure of Protection in Developing Countries. Baltimore: Johns Hopkins University Press.

Balassa, Bela. 1982. Development Strategies in Semi-Industrial Economies. Baltimore: Johns Hopkins University Press.

Baldinelli, Elvio. 1991. "Armonización de Políticas Fiscales, Crediticias, y de Promoción de Exportaciones." Integración Latinoamericana 16 (May).

Barro, Robert. 1991. "Economic Growth in a Cross-Section of Countries." Quarterly Journal of Economics 106 (2).

Bhagwati, Jagdish. 1978. Foreign Trade Regimes and Economic Development: Anatomy and Consequences of Exchange Control Regimes. Cambridge, Mass.: National Bureau of Economic Research.

Bianchi, Andres and Takahashi Nohara, eds., 1988. A Comparative Study on Economic Development between Asia and Latin America. Tokyo: Institute of Developing Economies.

Bonelli, Regis. 1992. "Growth and Productivity in Brazilian Industries: Impacts of Trade Orientation." Journal of Development Economics 39 (1).

Bruton, Henry. 1989. "Import Substitution." In Hollis Chenery and T. N. Srinivasan, eds., Handbook of Development Economics. Vol. 2. Amsterdam: North-Holland.

Calvo, Guillermo, Leonardo Leiderman, and Carmen Reinhardt. 1992. "Capital Inflows and Real Exchange Rate Appreciation." IMF Working Paper 62. International Monetary Fund, Washington, D.C.

Cardoso, Eliana, and Ann Helwege. 1992. Latin America's Economy: Diversity, Trends and Conflict. Cambridge, Mass.: MIT Press.

Castro, Antonio, and Carlos Lessa. 1969. Introducción a la Economía: Un Enfoque Estructuralista. Santiago: Editorial Universitaria.

CEPAl (Comisión Económica para América Latina). 1991. Balance Preliminar de la Economía de América Latina y el Caribe. Santiago: CEPAL.

CEPAL (Comisión Económica para América Latina). 1992. Equidad y Transformación Productiva: Un Enfoque Integrado. Santiago: CEPAL. 
CEPAL (Comisión Económica para América Latina). 1993. Statistical Yearbook of Latin America. Santiago: CEPAL.

Coes, Donald. 1991. "Brazil." In Michael Michaely, Armeane Choksi, and Demetris Papageorgiou, eds., Liberalizing Foreign Trade. New York: Basil Blackwell.

Corbo, Vittorio, Timothy Condon, and Jaime de Melo. 1985. "Productivity Growth, External Shocks, and Capital Inflows in Chile: A General Equilibrium Analysis." Journal of Policy Modelling 7 (3).

Corden, Warner Max. 1966. "The Structure of a Tariff System and the Effective Protection Rate." Journal of Political Economy 74 (3).

Corden, Warner Max. 1984. "The Normative Theory of International Trade." In Ronald Jones and Peter Kenen, eds., Handbook of International Economics, Vol. 1. Amsterdam, North-Holland.

De Gregorio, José. 1992. "Economic Growth in Latin America." Journal of Development Economics 39 (1).

Diaz-Alejandro, Carlos. 1970. Essays on the Economic History of the Argentine Republic. New Haven: Yale University Press.

Diaz-Alejandro, Carlos. 1978. Foreign Trade Regimes and Economic Development: Colombia. Cambridge, Mass.: National Bureau of Economic Research.

Diaz-Alejandro, Carlos. 1981. "Southern Cone Stabilization Plans." In William Cline and Sidney Weintraub, eds., Economic Stabilization in Developing Countries. Washington, D.C.: Brookings Institution.

Dixit, Avinash. 1986. "Tax Policy in Open Economies." In Alan Auerbach and Martin Feldstein, eds., Handbook of Public Economics. Amsterdam: North-Holland.

Dornbusch, Rudiger. 1989. “Los Costes y Beneficios de la Integración Económica Regional: Una Revisión." Pensamiento Iberoamericano 15 (January-June).

Dornbusch, Rudiger. 1991. "Policies to Move From Stabilization to Growth." Proceedings of the World Bank Annual Conference on Development Economics. Washington, D.C.: World Bank.

Dornbusch, Rudiger, and Sebastian Edwards. 1990. "Macroeconomic Populism." Journal of Development Economics 32 (2).

Edwards, Sebastian. 1984. "The Order of Liberalization of the External Sector in Developing Countries." Princeton Essays in International Finance No. 156. Princeton University, Princeton, N.J.

Edwards, Sebastian. 1985. "Stabilization with Liberalization: An Evaluation of Ten Years of Chile's Experiment with Free Market Policies, 1973-1983." Economic Development and Cultural Change 33 (January). 
Edwards, Sebastian. 1988. Exchange Rate Misalignment in Developing Countries. Baltimore: Johns Hopkins University Press.

Edwards, Sebastian. 1989. Real Exchange Rates, Devaluation, and Adjustment: Exchange Rate Policy in Developing Countries. Cambridge, Mass.: MIT Press.

Edwards, Sebastian. 1992. "Trade Orientation, Distortions and Growth in Developing Countries." Journal of Development Economics 39 (1).

Edwards, Sebastian. 1993a. "Exchange Rates as Nominal Anchors." Weltwirtschaftliches Archiv 129 (1).

Edwards, Sebastian. 1993b. "Openness, Trade Liberalization, and Growth in Developing Countries." Journal of Economic Literature, Vol. 31, September.

Edwards, Sebastian, and Alejandra Edwards. 1991. Monetarism and Liberalization: The Chilean Experiment. Chicago: University of Chicago Press.

Edwards, Sebastian, and Miguel Savastano. 1988. "Latin America's Intra-Regional Trade: Evolution and Future Prospects." NBER Working Paper 2738. National Bureau of Economic Research, Cambridge, Mass.

Elias, Victor. 1992. Sources of Growth: A Study of Seven Latin American Economies. San Francisco: ICS Press.

Erzan, Refik, Kiroaki Kuwahara, Saratino Marchese, and Rene Vossenar. 1989. "The Profile of Protection in Developing Countries." UNCTAD Review 1 (1).

Ffrench-Davis, Ricardo and Thomas Griffin. 1967. Teoria del Comercio Internacional. Mexico City: Fondo de Cultura Económica.

Fischer, Stanley. 1986. "Issues in Medium-Term Macroeconomic Adjustment." World Bank Research Observer 1 (2).

Fischer, Stanley. 1988. "Recent Developments in Macroeconomics." Economic Journal 98 (2).

Fishlow, Albert. 1985. "Revisiting the Great Debt Crisis of 1982." In Kwang Suk Kim and David Ruccio, eds., Debt and Development in Latin America. North Bend, Indiana: University of Notre Dame Press.

Fishlow, Albert. 1991. "Liberalization in Latin America." In Tariq Banuri, ed., Economic Liberalization: No Panacea. Oxford: Oxford University Press.

Furtado, Celso. 1969. La Economía Latinoamericana Desde la Conquista Ibérica Hasta La Revolución Cubana. Santiago: Editorial Universitaria.

Griffith-Jones, Stefany, and Osvaldo Sunkel. 1986. Debt and Development Crises in Latin America: 
The Ėd of an Illusion. Oxford: Oxford University Press.

Grossman, Gene, and Elhanan Helpman. 1991. Innovation and Growth in the Global Economy.

Cambridge, Mass.: MIT Press.

Hanson, James. 1992. "Opening the Capital Account." World Bank Policy Research Working Paper 901. Washington, D.C.

Harberger, Arnold. 1982. "The Chilean Economy in the 1970s: Crisis, Stabilization, Liberalization, Reform." In Karl Brunner and Allan Metzler, eds., Economic Policy in a World of Change, Carnegie-Rochester Conference Series on Public Policy, Vol. 17. Amsterdam: North-Holland.

Harberger, Arnold. 1985. "Observations on the Chilean Economy, 1973-1983." Economic Development and Cultural Change 33 (3).

Harberger, Arnold. 1990. "Towards a Uniform Tariff Structure." University of Chicago, Department of Economics.

Heitger, Bernhard. 1987. "Import Protection and Export Performance: Their Impact on Economic Growth." Weltwirtschaftliches Archiv 132 (2).

Hirschman, Albert. 1968. "The Political Economy of Import Substituting Industrialization in Latin America." Quarterly Journal of Economics 82 (1).

Ibarra, Luis. 1992. "Credibility of Trade Policy Reform: The Mexican Experience." Ph.D. diss., University of California, Los Angeles, Department of Economics.

Iglesias, Enrique. 1992. Reflections on Economic Development: Toward a New Latin American Consensus. Washington, D.C.: Inter-American Development Bank.

Kim, Kwang Suk. 1991. "Korea." In Michael Michaely, Armeane Choksi, and Demetris Papageorgiou, eds., Liberalizing Foreign Trade. New York: Basil Blackwell.

Krueger, Ann. 1978. Foreign Trade Regimes and Economic Development: Liberalization Attempts and Consequences. Cambridge, Mass.: National Bureau of Economic Research.

Krueger, Ann. 1980. "Trade Policy as an Input to Development." American Economic Review 70 (2).

Krueger, Ann. 1981. Trade and Employment in Developing Countries. Chicago: University of Chicago Press.

Krueger, Ann. 1983. Exchange Rate Determination. Cambridge, U.K.: Cambridge University Press.

Lal, Deepak. 1985. "The Real Aspects of Stabilization and Structural Adjustment Policies: An Extension of the Australian Adjustment Model." World Bank Staff Working Paper 636.

Washington, D.C. 
Lin, Ching-Yuan. 1988. "East Asia and Latin America as Contrasting Models." Economic Development and Cultural Change 36, S153-197 (April).

Little, Ian, Tibor Scitovsky, and Maurice Scott. 1970. Industry and Trade in Some Developing Countries. Oxford: Oxford University Press.

Losada, Fernando. 1993. "Parners, Neighbors and Distant Cousins: Explaining Bilateral Trade Flows in Latin America." Working paper, University of California, Los Angeles, June.

Losada, Fernando. 1994. "The Uruguay Round, GATT and Regionalism." Mimeo, World Bank, Latin America and the Caribbean Region - Office of the Chief Economist, March.

Lucas, Robert. 1988. "On the Mechanics of Economic Development." Journal of Monetary Economics 22 (1).

Lustig, Nora. 1994. "The Future of Trade Policy in Latin America." Working Paper, Brookings Institution, Washington, D.C., February.

Martin, Ricardo D. 1992. "Sources of Growth in Latin America." World Bank, Latin America and Caribbean Region, Washington, D.C.

McGreevey, William Paul. 1990. "Social Security in Latin America: Issues and Options for the World Bank." World Bank Discussion Paper 110. Washington, D.C.

McKinnon, Ronald. 1982. "The Order of Economic Liberalization: Lessons from Chile and Argentina." Carnegie-Rochester Conference Series on Public Policy, 17, Autumn.

Michaely, Michael. 1985. "The Demand for Protection against Exports of Newly Industrialized Countries." Journal of Policy Making 7 (1).

Michaely, Michael, Armeane Choksi, and Demetris Papageorgiou, eds. 1991. Liberalizing Foreign Trade. New York: Basil Blackwell.

Mill, John Stuart. 1884. Principles of Political Economy. New York: Appleton and Co.

Nogués, Julio, and Neera Gulati. 1992. "Economic Policies and Performance Under Alternative Trade Regimes: Latin America During the 1980s." LAC Technical Department Report 16. World Bank, Latin America and Caribbean Region, Washington, D.C.

Nogues, Julio, and Rosalinda Quintanilla. 1992. "Latin America's Integration and the Multilateral Trading System." Paper presented at the World Bank/CEPR Conference on New Dimensions in Regional Integration, Washington, D.C., April.

Ocampo, José Antonio. 1991. "Determinants and Prospects for Medium-Term Growth in Colombia." Paper presented at the Lehigh University Conference on the Colombian Economy: Issues of Debt, Trade, and Development, Lehigh University, Department of Economics, Bethlehem, Penn., April. 
Paz, Pedro, and Osvaldo Sunkel. 1971. El Subdesarrollo Latinoamericano y la Teorla del Desarrollo. Madrid: Siglo Veintiuno de España.

Prebisch, Raúl. 1950. "Commercial Policy in the Underdeveloped Countries." American Economic Review 40 (2).

Prebisch, Raúl. 1984. "Five Stages in my Thinking on Development." In Dudley Seers, ed., Pioneers in Development. Oxford: Oxford University Press.

Rodriguez, Carlos. 1982. "The Argentine Stabilization Plan of December 20th." World Development 10 (9).

Roubini, Nouriel, and Xavier Sala-i-Martin. 1992. "Financial Repression and Economic Growth." Journal of Development Economics 39 (1).

Saborio, Sylvia, and Constantine Michalopoulos. 1992. "Central America at a Crossroads." Policy Research Working Paper 922. World Bank, Washington, D.C.

Sachs, Jeffrey. 1987. "Trade and Exchange Rate Policies in Trade-Oriented Adjustment Programs." In Vittorio Corbo, Morris Goldstein, and Mohsin Khan, eds., Growth-Oriented Adjustment Programs. Washington, D.C.: International Monetary Fund.

Sachs, Jeffrey. 1988. "Conditionality, Debt Relief, and the Developing Country Debt Crisis. NBER Working Paper 2644. National Bureau of Economic Research, Cambridge, Mass.

Sanchez, Manuel. 1992. "Entorno Macroeconómico Frente al Tratado de Libre Comercio." In ITAM, Mexico: y el Tratado Trilateral de Libre Comercio. Mexico City: ITAM/McGraw-Hill.

Schott, Jeffrey. 1991. "Trading Blocks and the World Trading System." The World Economy 14 (1).

Sheahan, John. 1987. Patterns of Development in Latin America: Poverty, Repression, and Economic Strategy. Princeton, N.J.: Princeton University Press.

Singer, Hans. 1950. "The Distribution of Gains Between Investing and Borrowing Countries." American Economic Review 40 (2).

Solís, Leopoldo. 1988. "Raul Prebisch at ECLA: Years of Creative Intellectual Effort," ICEG Occasional Paper 10. International Center for Economic Growth, San Francisco.

Stockman, Alan C. 1982. "The Order of Economic Liberalization: Comment." In Karl Brunner and Allan Meltzer, eds., Economic Policy in a World of Change. Amsterdam: North-Holland.

Sturzenegger, Federico. 1992. "Bolivia: Stabilization and Growth." University of California, Los Angeles, Department of Economics.

Summers, Robert, and Alan Heston. 1988. "A New Set of International Comparisons of Real Product and Price Level Estimates for 130 Countries." Review of Income and Wealth 34 (March). 
Sunkel, Osvaldo. 1960. "Inflation in Chile: An Unorthodox Approach." Intemational Economic Papers 10 (August).

Taylor, Lance. 1991. "Economic Openness: Problems to the Century's End." In Tariq Banuri, ed., Economic Liberalization: No Panacea. New York: Clarendon Press.

Thorp, Rosemary. 1992. "A Reappraisal of the Origins of Import-Substitution Industrialization, 1930-1950." Journal of Latin American Studies 24 (supplement).

Tybout, James. 1992. "Linking Trade and Productivity: New Research Directions." World Bank Economic Review 6 (2).

Valdés, Alberto. 1992. "The Performance of the Agricultural Sector in Latin America." World Bank, Latin America and Caribbean Region, Washington, D.C.

Vuskovic, Pedro. 1970. "Distribución del Ingreso y Opciones de Desarrollo." Cuadernos de la Realidad Nacional 7 (September).

Weiss, John. 1992. "Trade Policy Reform and Performance in Manufacturing: Mexico 1975-1988." Journal of Development Studies 29 (1).

World Bank. 1987. World Development Report. New York: Oxford University Press.

World Bank. 1993. The Asian Economic Miracle: Economic Growth and Public Policy. New York: Oxford University Press. 